\title{
De Gentse Sint-Lucasgilde: kunstenaars in de periode 1574-1773. Een prosopografische benadering. 1
}

\author{
Tim De Doncker
}

Een van de aspecten in de vroegmoderne maatschappij die herhaaldelijk op interesse van historici kon rekenen zijn de beeldende kunsten. Dit is eveneens het geval voor de stad Gent in de vroegmoderne periode. Al te vaak blijkt echter dat de kunstenaars zelf, zeker indien het geen sleutelfiguren à la Rubens betroffen, buiten het onderzoeksperspectief blijven. Dit artikel stelt zich de vraag naar wat de socio-economische positie van de Gentse kunstenaar was gedurende de periode $1574-1773 .^{2}$

In navolging van Peter Burke ${ }^{3}$ worden hier de kunstenaars als collectiviteit bestudeerd. Dit verklaart de prosopografische basis van het gevoerde onderzoek. Een prosopografie is immers niets anders dan een collectieve biografie van een groep mensen die een gemeenschappelijk kenmerk hebben, in dit geval het lidmaatschap van de Gentse Sint-Lucasgilde. De historicus Daniël Jeen Roorda, een van de voortrekkers van prosopografisch onderzoek in Nederland, prees deze onderzoeksmethode expliciet aan voor het onderzoek naar kunstenaars. ${ }^{4}$

Gedurende de bestudeerde periode waren de drie grootste steden in de Zuidelijke Nederlanden Antwerpen, Brussel en Gent. ${ }^{5}$ In vergelijking met beide andere steden speelde de Arteveldestad echter geen prominente rol op het vlak van de kunstindustrie. Brussel huisvestte een weelderig hof, waar, ondanks de oorlogsperikelen, regelmatig financiële ruimte was voor het aanschaffen van kunst. ${ }^{6}$ Antwerpen was zonder meer hét kunstcentrum der Nederlanden. De verhalen over de Gouden Eeuw zijn genoegzaam bekend. Hand in hand met de toenemende welvaart kende de Scheldestad een ongekende culturele bloei. Deze gunstige periode werd, zeker op kunstgebied, niet abrupt afgebroken door de Val van Antwerpen in 1585. Namen van schilders als Peter Paul Rubens, Antoon van Dyck en Theodoor Rombouts of de beeldhouwer Artus Quellinus illustreren vermoedelijk nog het best de culturele rijkdom van Antwerpen gedurende de $17^{\text {de }}$ eeuw en verder. Voor diegenen die de kunstontwikkelingen volgden was Antwerpen the place to be. Daarentegen bleek Gent tijdens de $17^{\mathrm{de}}$ en $18^{\mathrm{de}}$ eeuw "slechts" een provinciestad met een regionale uitstraling. ${ }^{7}$

Toch dient men echter Gent op artistiek vlak geen marginale rol toe te schrijven. Onze onderzoekspopulatie bestaat immers uit de maar liefst 988 verschillende individuen die terug te vinden zijn op de bestuurs- en ledenlijsten van de Gentse Sint-Lucasgilde in de 200 jaar durende tijdspanne van 1574 tot en met 1773. Deze data zijn trouwens niet willekeurig gekozen. Een gelijkaardige studie werd reeds ondernomen voor het laatmiddeleeuwse Gent

\footnotetext{
${ }^{1}$ Dankbaarheid ben ik verschuldigd aan Anne-Laure van Bruaene voor de nuttige tips en suggesties.

${ }^{2}$ Deze bijdrage kwam tot stand naar aanleiding van mijn licentiaatverhandeling T. DE DONCKER, Gentse kunstenaars, eenheid en diversiteit. Sociaaleconomische studie op basis van een prosopografisch onderzoek, Licentiaatverhandeling, Universiteit Gent (Gent, 2007), 3 dln. Deel twee en drie van deze scriptie bevatten informatie over de vermelde kunstenaars, samen met de gebruikte bronnen en literatuur.

${ }^{3}$ P. BURKE, The Italian Renaissance. Culture and society in Italy (Cambridge, 1986).

${ }^{4}$ D.J. ROORDA, "Prosopografie, een onmogelijke mogelijkheid?", Bijdragen en Mededelingen betreffende de geschiedenis der Nederlanden, 94 (1979), pp. 212-225.

${ }_{5}^{5}$ F. VERLEYSEN, Het hemelse festijn. Religieuze cultuur, sociabiliteit en sociale relaties in de corporatieve wereld van Antwerpen, Brussel en Gent (ca. 1585 - ca. 1795), Doctoraatproefschrift, Vrije Universiteit Brussel (Brussel, 2005), p. 8.

${ }^{6}$ J. DUVERGER, Kunstgeschiedenis der Nederlanden: Deel III: van het einde van de zestiende eeuw tot onze tijd in Zuid-Nederland (Utrecht-Antwerpen, 1956), p. 10.

${ }^{7}$ DUVERGER, Kunstgeschiedenis der Nederlanden, p. 9.
} 
(1400-1500) door Els Cornelis. ${ }^{8}$ Logischerwijs zou het gevoerde onderzoek dienen aan te sluiten bij dit van Cornelis. Pragmatische redenen verhinderden dit echter. Het leden- en inschrijvingsregister van de Sint-Lucasgilde, bewaard in het Gentse stadsarchief (SAG), overloopt vanaf het jaar 1339 tot en met het jaar 1713 de bestuursleden van de gilde, samen met de nieuw ingeschreven vrijmeesters. Er dook echter een probleem op. Victor Van der Haeghen stelde vast dat de eerste folio's van het register het product waren van een handige falsaris uit de eerste helft van de $19^{\text {de }}$ eeuw. Bij de externe kritiek wees Van der Haeghen op de vernuftige middeltjes die door de falsaris werden aangewend: de oorspronkelijke paginering werd verwijderd met een zuuroplossing, enkele beschreven bladen werden wit gemaakt, er werd $17^{\mathrm{de}}$ - of $18^{\mathrm{de}}$ - eeuws papier toegevoegd en ook de rug van het boek werd vernieuwd. Naast een groot aantal grammaticale en taalkundige fouten merkte Van der Haeghen ook de weinig accurate imitatie van het $16^{\text {de }}$-eeuwse schrift op. ${ }^{9}$ Er werd dan ook geopteerd om het onderzoek te starten in het jaar 1574, het eerste jaar waarvoor de lijst als authentiek te beschouwen is. De motivering voor het eindjaar 1773 is minder pragmatisch. Maria Theresia besloot op 13 november 1773 bij decreet dat de schilder-, beeldhouw-, graveerkunst en architectuur onafhankelijk dienden te worden van eender welke vereniging. Voortaan kon iedereen vrij deze kunsten beoefenen en zijn werken verkopen zonder zich eerst in te schrijven in een ambacht, een gilde of eender welk gezelschap. ${ }^{10}$

Inhoudelijk zal dit artikel vervolgen met een algemene schets van de Sint-Lucasgilde en zijn leden, met andere woorden de onderzoekspopulatie. Nadien zal aan de hand van de verschillende sociaaljuridische niveaus binnen het ambacht (leerling, knecht, meester, bestuurslid) de sociaaleconomische positie van de kunstenaar in kaart gebracht worden.

\section{De Gentse Sint-Lucasgilde}

\subsection{Geschiedenis}

De gilden van de Heilige Lucas, beter gekend onder de benaming Sint-Lucasgilden dateerden uit de middeleeuwen. De naam van de gilde was afkomstig van Lucas de Evangelist, die leefde in Antiochië in de eerste eeuw n.C. en arbeid verrichtte als arts en schilder. De legende gaat dat hij het eerste portret van Maria schilderde. ${ }^{11}$ Voor de stad Gent is het exacte tijdstip van de definitieve vorming van het ambacht niet te bepalen. De eerste vermelding van de nering der schilders dateert uit het jaar 1356, maar voordien kwamen al namen van schilders, beeldhouwers en glazeniers voor in de schepenregisters en de stadsrekeningen. ${ }^{12}$

De gebeurtenissen in de $16^{\text {de }}$ eeuw hadden een belangrijke impact op de geschiedenis van het ambacht. De Concessio Carolina uit 1540 reorganiseerde in grote mate het stedelijke leven en legde voor bijna drie eeuwen de politieke, economische en sociale structuren van de Gentse samenleving vast. Concreet hield dit onder meer het einde van de formele politieke macht van

\footnotetext{
${ }^{8}$ E. CORNELIS, De kunstenaar in het Laat-Middeleeuws Gent, Licentiaatverhandeling, Universiteit Gent (Gent, 1984), 2 dln.

${ }^{9}$ CORNELIS, De kunstenaar, I, pp. 4-5.

${ }^{10}$ STADSARCHIEF GENT (verder SAG), Reeks 183-3, Reglementen, 1657-1775.

${ }^{11}$ M. NORTH, Art and commerce in the Dutch Golden Age (New Haven, 1997), p. 68. Het thema "De H. Lucas schildert de Maagd" komt veelvuldig voor in de schilderkunst. Bekende voorbeelden zijn van de hand van Jan Gossaert (Praag, Narodni Galerie; Wenen, Kunsthistorisches Museum) en Maarten van Heemskerck (Haarlem, Frans Halsmuseum).

${ }^{12} \mathrm{~V}$. VAN DER HAEGHEN, Mémoire sur les documents faux relatifs aux anciens peintres, sculpteurs et graveurs flamands (Brussel, 1899), p. 34; SAG, Nota's van Werveke 1169, Nering der schilders; CORNELIS, De kunstenaar, I, p. 13.
} 
de ambachten in. ${ }^{13}$ Bovendien werd bepaald dat elke Gentse burger kon intreden in een gilde, na het maken van een proefstuk en na het betalen van 10 gouden carolusmunten "pour toutes choses". Meer concreet werden de kunstenaars (schilders, beeldhouwers, glazenmakers en goudslagers) gevoegd bij de meerseniers, en de riem- en hoedenmakers. Later sloten ook de wasgieters en borduurders aan. ${ }^{14}$

De tijdspanne tussen de uitvaardiging van deze nieuwe statuten en het jaar 1574 werd gekenmerkt door een sluimerende activiteit. Bij gebrek aan residerende kunstenaars werd de bedrijvigheid van het ambacht nauwelijks hernomen. Deze periode van neergang werd meerdere malen onderbroken door een wederopleving, zonder dat het ambacht weer op regelmatige basis functioneerde. ${ }^{15}$ Gedurende deze periode stichtte Lucas d'Heere $\left({ }^{\circ} 1534-\dagger\right.$ 1584) te Gent een schilderschool waarin onder meer Carel van Mander, de Bruggeling Marcus II Gheeraerds, Joos en Willem Borluut hun opleiding kregen. ${ }^{16}$

Op kerstmis 1574, gedurende een periode van recessie, slaagde men erin de gilde weer op de been te brengen. ${ }^{17}$ Het is dan ook niet toevallig dat de eerste niet betwistbare gegevens uit het Schildersboeck dateren uit het jaar 1574. Deze nieuwe start valt niet enkel af te leiden uit het inschrijvingsregister. Dadelijk deed men verwoede pogingen de misbruiken uit de voorgaande jaren uit te roeien. Het ambacht richtte zich uitdrukkelijk tegen de verkoop van werken van vreemde origine buiten de periodes van de vrije jaarmarkten. De kunstenaars haalden hun slag thuis. In 1575 bevestigde een schepenordonnantie het verbod van dergelijke verkopen op het stadsterrein. Bovendien werden ook de personen die opdrachten uitvoerden zonder eerst de vrijheid van het ambacht te verwerven persona non grata. ${ }^{18}$

De goede bedoelingen en de nieuwe start ten spijt, zorgde de terugkeer van de religieuze troebelen voor een versnippering van het ambacht. Tijdens de beginperiode van de Calvinistische Republiek te Gent (1577-1584) verwaterde het ambacht. Vanaf de jaren 15821583 begon de Sint-Lucasgilde terug op een meer regelmatige basis te functioneren. Bovendien slaagde men erin enkele, door de Carolijnse Concessie van 1540, verloren voorrechten terug te winnen. ${ }^{19}$

De verzoening van de calvinistische stad met Farnese betekende voor de vereniging van de kunstenaars wederom een nieuwe start. De eerste jaren waren er van vallen en opstaan. Uit de periode 1585-1594, de eerste 10 jaar na de onregelmatigheden, bevat het inschrijvingsregister van de kunstenaarsgilde enkel de jaren 1587, 1590 en 1591. Vanaf het jaar 1595 lijkt het ambacht weer te functioneren op regelmatige basis. ${ }^{20}$ Deze periode waarin de gilde een belangrijke rol speelde, liep tot diep in de $18^{\text {de }}$ eeuw, meer bepaald tot het jaar $1773 .^{21}$

\footnotetext{
${ }^{13}$ J. DAMBRUYNE, "De Gentse bouwvakambachten in sociaal-economisch perspectief (1540-1795)", in C. LIS, H. SOLY (eds.), Werken volgens de regels. Ambachten in Brabant en Vlaanderen, 1500-1800 (Brussel, 1994), p. 52.

${ }^{14}$ V. VAN DER HAEGHEN, La corporation des peintres et des sculpteurs de Gand. Matricule, comptes et documents $\left(16^{\mathrm{e}}-18^{\mathrm{e}}\right.$ siècles) (Gent, 1905-1906), p. 118; E. DE BUSSCHER, Recherches sur les peintres et sculpteurs à Gand, aux XVIe, XVIIe et XVIII siècles (Gent, 1866), p. 113; SAG, Nota's van Werveke, 1169.

${ }^{15}$ DE BUSSCHER, Recherches sur les peintres, p. 113.

${ }^{16}$ E. BAES, La peinture flamande et son enseignement sous le régime des confréries de St-Luc (Brussel, 1882), p. 139; J.P. DE BRUYN, "Schilderkunst van de $15^{\text {de }}$ tot de $17^{\text {de }}$ eeuw", in Catalogus. Gent, duizend jaar kunst en cultuur. Catalogus van het Museum voor Schone Kunsten te Gent, 19 april-29 juni 1975, I, p. 138; M. RUDELSHEIM, "Lucas d'Heere", Oud Holland, 21 (1903, 2), p. 2.

${ }^{17}$ DE BUSSCHER, Recherches sur les peintres, p. 113; J. DAMBRUYNE, Mensen en centen. Het $16^{\mathrm{de}}$-eeuwse Gent in demografisch en economisch perspectief (Gent, 2001), p. 348.

${ }^{18}$ DE BUSSCHER, Recherches sur les peintres, p. 113-114; SAG, Reeks 183-1, fol. 19, 20v, 21, $21 \mathrm{v}$.

${ }^{19}$ DE BUSSCHER, Recherches sur les peintres, p. 114.

${ }^{20}$ De door Van der Haeghen uitgevoerde transcriptie vermeldt ook de gegevens van 1593 (VAN DER HAEGHEN, La corporation des peintres, p. 22). De eigen uitgevoerde transcriptie van het Schildersboeck geeft echter de voorkeur het jaartal op folio 49 te lezen als 1595.

${ }^{21}$ SAG, Reeks 183-3.
} 


\subsection{Populatie}

Het samenstellen van de populatie van de Sint-Lucasgilde verliep niet zonder slag of stoot. Een zorgvuldig, overzichtelijk bijgehouden register van het ledenbestand voor de volledige onderzoeksperiode is niet voor handen. Ondanks deze beperking was het toch mogelijk op basis van verschillende bronnen de kunstenaars die verbonden waren met de nering te traceren.

Een eerste belangrijk hulpmiddel was het Schildersboeck. ${ }^{22}$ Het behelst een overzicht van de nieuw ingeschreven leden en het bestuur gedurende de periode 1339-1713. De gegevens voor de periode 1574-1713 zijn niet het resultaat van een vervalser en werden dus opgenomen in dit onderzoek. De extracten van de schildersboeken werden eveneens ter hand genomen. ${ }^{23} \mathrm{Bij}$ de uitgaven in de corporatieve rekening van 1714-1716 staat onder meer: "...betaelt voor eenen nieuwen boec ten dienste van de neirijnghe omme daer op t'annoteren soo de nieuwe meesters als anderssints...". ${ }^{24}$ Dit tweede boek is echter niet bewaard, in tegenstelling tot afschriften hiervan. Dit zijn de extracten. Naast informatie uit de periode vóór het jaar 1714 die reeds te vinden is in het Schildersboeck, bevat deze bron de namen van de nieuw ingeschreven leden en de leiding van de nering voor de jaren 1714 tot en met 1735. Tot slot werden de grosso modo laatste 40 jaren van het ledenbestand van de Sint-Lucasgilde samengesteld via het aanwenden van de corporatieve rekeningen. ${ }^{25}$ Net zoals allerhande hedendaagse organisaties en verenigen, hield de Sint-Lucasgilde een boekhouding bij. Een Gentse schepenordonnantie, gedateerd 6 april 1542, bepaalde immers duidelijk dat de aftredende oversten en gezworenen rekenschap dienden af te leggen van hun mandaat, in aanwezigheid van de schepenen en de nieuwe bestuursleden. Een nieuw intern reglement van de kunstenaarsnering uit 1657 stipuleerde bovendien dat het aftredend bestuur 8 dagen na het verstrijken van hun mandaat de rekeningen dienden binnen te brengen. ${ }^{26}$ Het bestuur van de gilde is terug te vinden in de aanhef van de rekening, die steeds uit dezelfde formele structuur bestaat. Enkel de namen van de bestuursleden en de jaartallen waarop de rekening betrekking heeft, wijzigen in deze beginformulering. In deze rekeningen werden, naast de verschillende uitgavenposten, ook de inkomsten opgetekend. De beschikking uit 1542 vermeldde eveneens dat elke Gentse burger de vrijheid van een corporatie kon verwerven na het produceren van een aanvaard proefstuk en het betalen van 6 gouden carolusmunten. Een nieuwe meester diende dus eenmalig inschrijvingsgeld te betalen. Hierdoor is het mogelijk op basis van de rekeningen de leden van de Sint-Lucasgilde op te sporen. Dit type bron is echter niet beschikbaar voor de hele onderzoeksperiode. Een nota in het Schildersboeck bij het jaar 1653 vermeldt "dit is de eerste rekeninghe voor dheeren schepenen". ${ }^{27}$ De rekeningen of gelijkaardige documenten van voor 1653 zijn niet bewaard.

Het Schildersboeck, de extracten en de rekeningen stelden mij in staat om het volledige ledenbestand van de Sint-Lucasgilde te Gent in de periode 1574-1773 te reconstrueren. Eens via deze weg de onderzoekspopulatie was samengesteld, behelsde de volgende stap het verzamelen van zo veel mogelijk gegevens die een inkijk geven in het leven van de desbetreffende gildenleden. De data hebben zowel betrekking op het professionele leven als het privéleven van de kunstenaars. Door de aard van het onderwerp en het type onderzoek was het mogelijk een gevarieerd gamma bronnen aan te wenden. Bovendien werden gegevens

\footnotetext{
${ }^{22}$ SAG, Reeks 183-1.

${ }^{23}$ SAG, Reeks 183-2, Extracten uit de schildersboeken (1602-1737).

${ }^{24}$ SAG, Reeks 183-5, 1714-1716.

${ }^{25}$ SAG, Reeks 183-5.

${ }^{26}$ SAG, Reeks 183-3.

${ }^{27}$ SAG, Reeks 183-1, fol. 93.
} 
met betrekking tot de populatie ook teruggevonden in de literatuur.

\subsection{Professionele diversiteit}

Alle onderzochte individuen maakten deel uit van één en dezelfde organisatie, het SintLucasambacht. Toch bestond er een interne opdeling. De nering kan aldus beschouwd worden als de overkoepelende structuur die de verschillende kunstenaarsgroeperingen of de verschillende beroepen onder zich verenigde. De corporatie werd derhalve gekenmerkt door een meerledige structuur, die gedurende het verloop van de vroegmoderne periode enigszins varieerde.

De samenstelling van de gilden verschilde van stad tot stad. In Amsterdam ressorteerden tapijtwevers onder het ambacht. In Leiden hadden de glazenmakers en de schilders hun eigen corporatie. ${ }^{28}$ In Antwerpen maakten bijvoorbeeld ook boekbinders, koffermakers en klavecimbelmakers deel uit van het ambacht. ${ }^{29}$ De situatie in Gent was nog anders.

Dambruyne stelt in zijn essay over de Gentse bouwvakambachten dat het Sint-Lucasambacht sinds de middeleeuwen samengesteld was uit vier grote afdelingen: (1) de kunst- en kladschilders, (2) de beeldhouwers, (3) de glazenmakers en (4) de stoffeerders. ${ }^{30}$ In deze studie, waar de gilde van Sint-Lucas en zijn leden het centrale onderwerp vormen, is het echter noodzakelijk dit verder uit te werken en te preciseren. De kunstenaarspopulatie is immers gediversifieerder dan Dambruyne laat uitschijnen.

De professionele activiteit van het merendeel van de leden is gekend, aangezien deze informatie vaak opgetekend is, zowel in het Schildersboeck, als in de extracten en rekeningen. Deze bronnen maken gewag van niet minder dan 34 verschillende beroepsactiviteiten, met name architect (1), beeldjesgieter (1), beeldhouwer (25), beeldsnijder (107), boetseerder (2), bordschilder (1), borduurder (34), fijnschilder (83), glazenier (9), glazenmaker (194), goudslager (10), huis- of kladschilder (103), koopman van schilderijen (4), landschapschilder (6), marmeraar (11), muurwitter of -kalker (1), orgelmaker (1), ornamentbeeldhouwer (13), prentverkoper (6), schilder (143), steenhouwer (16), stoelschilder (4), stofdrukker (2), stoffeerder (74), stoffeerder van beeldjes (1), stoffeerder van plaaster (1), tafelschilder (1), vergulder (9), verkoper van wassen voorwerpen (1), (ver)lakker (1), verluchter (2), wagenmaker (1), wasgieter (4) en zerksteenhouwer (1). ${ }^{31}$

Met 39,63\% vormden de schilders de grootste groep in het Sint-Lucasambacht. Binnen dit lid is het echter noodzakelijk een verdere onderverdeling door te voeren. Een eerste groep bestond uit de witters of huis- of kladschilders, uitzonderlijk ook clackschilders of platschilders genaamd. Het beroepsmonopolie van deze groepering behelsde het uitvoeren van buiten- en binnenschilderwerk. Het penseel werd gehanteerd voor het schilderen van gevels, poorten, deuren en vensters. ${ }^{32}$ Men dient hen te onderscheiden van de tweede groep, de fijnschilders. Dezen bezaten het alleenrecht voor het vervaardigen en verkopen van schilderijen. Bovendien hadden enkel dezen het recht om beelden te polychromeren. In de bouwsector waren deze kunstschilders verantwoordelijk voor het uitvoeren van decoratieve plafond-, schouw- en wandschilderkunst. ${ }^{33}$ Vanaf 1735 bleven echter enkel de fijnschilders over in het ambacht. Op 28 oktober 1734 dienden de huisschilders immers een rekwest in bij de schepenen van de keure met het verzoek om zich te mogen afkeren van het Sint-

\footnotetext{
${ }^{28}$ NORTH, Art and commerce, p. 68-69.

${ }^{29}$ P. ROMBOUTS, T. VAN LERIUS, De Liggeren en andere historische archieven der Antwerpsche Sint Lucasgilde, onder zinspreuk: Wt ionsten versaemt (Antwerpen, 1872-1876), II, p. 29, 129, 137.

${ }^{30}$ DAMBRUYNE, De Gentse bouwvakambachten, p. 54.

${ }^{31}$ Tussen haakjes wordt steeds het totale aantal vermeldingen weergegeven.

${ }^{32}$ J. DAMBRUYNE, Corporatieve middengroepen. Aspiraties, relaties en transformaties in de $16^{\mathrm{de}}$-eeuwse Gentse ambachtswereld (Gent, 2002), p. 27.

${ }^{33}$ DAMBRUYNE, Corporatieve middengroepen, p. 27; DAMBRUYNE, De Gentse bouwvakambachten, p. 54.
} 
Lucasambacht, waaronder zij sinds de middeleeuwen ressorteerden. De kladschilders namen het niet langer dat de fijnschilders "den baes spelen" en zich niet bezig hielden met het algemeen belang van de corporatie. Ze bekloegen zich erover dat de gezworenen, gekozen uit de eerste drie secties van de nering (fijnschilders, beeldhouwers en glazenmakers), zich nauwelijks bezig hielden met overtredingen gesignaleerd door de huisschilders en niets deden om de rechten en prerogatieven van de kladschilders te bewaren, ondanks het feit dat zij in grote mate bijdroegen aan de financiële inkomsten van de vereniging. Het schepencollege gaf op 31 januari 1735 zijn fiat tot de oprichting van een eigen ambacht. De witters stonden voortaan op eigen benen als leden van een onafhankelijk ambacht. ${ }^{34}$ Deze afscheiding van de huisschilders gebeurde niet toevallig in de $18^{\text {de }}$ eeuw. De witters kenden een gunstige economische ontwikkeling, aangezien de $18^{\mathrm{de}}$-eeuwse bouwstijlen een grote plaats toekenden aan het binnen- en buitenschilderwerk. ${ }^{35}$ Als groep werden ze steeds belangrijker, maar de andere leden van de gilde namen hen niet au sérieux. Een afsplitsing was onvermijdelijk.

De tweede beroepsgroep binnen het kunstenaarsambacht werd gevormd door de sculpteurs. Deze groep vertegenwoordigt $18,90 \%$ en bezat het alleenrecht voor het vervaardigen en verkopen van decoratief sculptuurwerk. ${ }^{36}$ Binnen deze groep vormen de beeldsnijders $(64,85$ $\%)$ en beeldhouwers $(15,15 \%)$ de grootse deelpopulaties. Het onderscheid tussen beide situeert zich op het vlak van het gebruikte materiaal. Waar hout de grondstof is van de eerste, is steen het basismateriaal van de tweede. Dit onderscheid viel echter weg aan het begin van de $17^{\text {de }}$ eeuw bij de opkomst van de barok. Voortaan bewerkte men in eenzelfde atelier zowel steen als hout. ${ }^{37}$ Opmerkelijk is verder de aanwezigheid van steenhouwers in het SintLucasambacht. Hoe moeilijk deze in bepaalde gevallen ook te onderscheiden waren van de beeldhouwers, toch maakten ze sinds 1540 deel uit van een verschillende nering. De Carolijnse Concessie bepaalde immers dat de steenhouwers samen met de metselaars een tweeledige nering vormden. ${ }^{38}$ Toch doken meerdere steenhouwers op in de kunstenaarsnering. Een mogelijke verklaring is dat gedurende de vroegmoderne periode het onderscheid steenhouwer-sculpteur niet steeds voor de hand lag en de grenzen tussen de ambachten niet zo strak uitgetekend waren als de naamgeving en onderverdeling van de neringen zou kunnen laten vermoeden.

Het derde let van de nering verzamelde de glasvervaardigers. Het betreft hoofdzakelijk glazenmakers $(95,57 \%)$. De overblijvende fractie werd gevormd door de glasschilders. De glazeniers hadden sinds de middeleeuwen het exclusieve recht om glazen vensters te fabriceren en te plaatsen. Ook het aanbrengen van ruitjes in de raamopeningen met behulp van lood behoorde tot hun takenpakket. Tot in de $16^{\text {de }}$ eeuw was de glazenier ook steeds glasschilder, en stond hij dus in voor zowel het vervaardigen, snijden en aanbrengen van het glas in de raamopeningen, als het beschilderen ervan. ${ }^{39}$ Door de voortdurende toename van de vraag naar neutraal glas vond er echter vrij snel een ontkoppeling plaats van het beroep van glazenmaker en glasschilder. ${ }^{40}$

Nog twee andere groepen zijn het vermelden waard, met name de stoffeerders $(8,71 \%)$ en de borduurders $(3,89 \%)$. Deze laatsten vonden pas aansluiting bij het schildersambacht in $1630 .{ }^{41}$

\footnotetext{
${ }^{34}$ SAG, 156bis nr. 59, Huisschilders (1736-1791).

${ }^{35}$ DAMBRUYNE, De Gentse bouwvakambachten, p. 61.

${ }^{36}$ DAMBRUYNE, De Gentse bouwvakambachten, p. 53.

${ }^{37}$ DUVERGER, Kunstgeschiedenis der Nederlanden, p. 118.

${ }^{38}$ J. DAMBRUYNE, "Het werkkader van de bouwsector: de ambachtsgilden", in J. DAMBRUYNE, G.J. BRAL, A. RAMBAUT, D. LAPORTE (eds.), Een stad in opbouw: Gent van 1540 tot de Wereldtentoonstelling van 1913 (Tielt, 1992), p. 130.

${ }^{39}$ DAMBRUYNE, Het werkkader van de bouwsector, p. 139; DAMBRUYNE, De Gentse bouwvakambachten, p. 54.

${ }^{40}$ J. HELBIG, Meesterwerken van de glasschilderkunst (Antwerpen-Utrecht, 1941), pp. 21, 31.

${ }^{41}$ SAG, Nota's Kluyskens 16, Rynck Jacobus de of de Rinck.
} 
Deze intrede van de borduurwerkers ging echter niet zonder slag of stoot en verliep meer dan waarschijnlijk geleidelijk. In 1676 vroegen de schilders met de naald immers aan de nering of het mogelijk was om de ordonnantie van de nering aan te passen, aangezien "dat onder hun is sorterende de borduijrders van over twintich, dertich ende meer jaeren". De nering was echter niet helemaal overtuigd en contacteerde de Antwerpse gilde van Sint-Lucas. De dekens van deze organisatie deelden mee dat te Antwerpen de borduurwerkers deel uitmaakten van de gilde. Op 24 september 1676 ten slotte vaardigden de schepenen van de keure een document uit, waarin opgetekend stond dat elke persoon die zich bezig hield met het vervaardigen van borduurwerk lid kan worden van de kunstenaarsnering. ${ }^{42}$ Vanaf 1718 liep de relatie van de borduurwerkers met de kunstenaarsnering echter spaak. Van toen af aan weigerden zij immers hun ommestellijnghe, een jaarlijkse bijdrage in de kas van het ambacht, te betalen. Vanaf 1730 is er geen enkel spoor meer terug te vinden van borduurwerkers in het Sint-Lucasambacht. De borduurders gingen hun eigen weg op, los van het schildersambacht, waar ze een eeuw aansluiting hadden bij gevonden. ${ }^{43}$

\section{Carrièreverloop}

Bepaalde factoren, zoals het opgroeien in een artistiek milieu en/of natuurlijke begaafdheid, konden de latere beroepskeuze vanzelfsprekend positief beïnvloeden. Toch diende iedereen dezelfde stappen te doorlopen, alvorens zelfstandig actief te kunnen zijn als kunstenaar. Het ambachtswezen bezat immers een sterk hiërarchische structuur. Bij elk ambacht is het dan ook mogelijk vier sociaaljuridische niveaus te onderscheiden met specifieke rechten en plichten. In opklimmende volgorde betreft het de leerling, de knecht, de meester en het bestuurslid. $^{44}$

\subsection{Opleiding}

Alvorens men vrij een beroep, dat ressorteerde onder het Gentse Sint-Lucasambacht, kon uitoefenen, diende men een leertijd door te maken. De duur van deze opleidingsperiode in de Sint-Lucasgilde, een corporatie met een hoge artistieke kwalificatiegraad, is niet gekend. Voor de periode $1500-1540$ kon deze vorming oplopen tot 8 jaar. ${ }^{45}$ De Jager stelt hiertegen wel dat een opleidingsduur van drie à vier jaar in de praktijk volwaardig werd gevonden. ${ }^{46}$ Bovendien geschiedde deze opleiding van een kunstenaar in spe niet kosteloos, zoals blijkt uit het contract opgemaakt tussen de schilder Anselmus Hebbelynck alias van Hulle en Jan du Quesne. ${ }^{47}$ Ouders die hun zonen in de leer stuurden ambieerden voor hun kroost een aan gewone knechten superieure status. Via een leertijd werd dus een distinctie ten opzichte van andere sociale categorieën aangebracht. ${ }^{48}$

Een gunstige maatschappelijke positie was echter geen voldoende voorwaarde om als kunstenaar opgeleid te worden. De jongens in opleiding - meisjes konden het beroep immers niet aanleren ${ }^{49}$ - dienden daarenboven conform te zijn aan enkele bepalingen. Eén van deze

\footnotetext{
${ }^{42}$ SAG, Reeks 183-1, fol. 106, 106 v en 107.

${ }^{43}$ SAG, Reeks 183-5, 1730-1733; SAG, Nota's Kluyskens 16.

${ }^{44}$ DAMBRUYNE, De Gentse bouwvakambachten, p. 62.

${ }^{45}$ DAMBRUYNE, Corporatieve middengroepen, p. 183.

${ }^{46}$ R. DE JAGER, "Meester, leerjongen, leertijd. Een analyse van zeventiende-eeuwse Noord-Nederlandse leerlingencontracten van kunstschilders, goud- en zilversmeden" Oud Holland, 104 (1990, 2), p. 70.

${ }^{47}$ SAG, Nota's van der Haeghen, H1.

${ }^{48}$ B. DE MUNCK, D. DENDOOVEN, Al doende leert men: leertijd en ambacht in het Ancien Régime (15001800) (Brugge, 2003), pp. 24-25, 36.

${ }^{49}$ Over de aanwezigheid van vrouwen in de gilde, zie verder.
} 
noodzakelijke vereisten betrof het poorterschap. ${ }^{50}$ Voor de leerjongens was geen minimumleeftijd bepaald, maar wanneer de aspirant de leeftijd van 12 jaar bereikte, werd hij in staat geacht om het ambacht aan te leren. ${ }^{51}$ Dit bleek echter geen dwingende regel.

In de praktijk diende men het beroep bij een vrijmeester aan te leren. Niet elke meester kwam echter in aanmerking voor het opleiden van één of meerdere leerlingen. Het aannemen van een aspirant betekende immers een vertrouwen in het potentieel, zowel van de meester als van de leerling.

Het verwerven van het vak gebeurde aldus op de werkvloer. Speciale vakscholen bestonden immers niet. ${ }^{52}$ In de Zuidelijke Nederlanden werd de eerste academie naar Italiaans model pas opgericht in 1663 te Antwerpen. ${ }^{53}$ Gent volgde in 1751 met als drijvende kracht Philippe Charles Marissal. Deze onderwijsinstituties dient men echter te zien als een middel om zich binnen de gilde op te werken. De academies stonden immers naast, eventueel boven, de gilde, maar ze waren niet in strijd met de gilde. ${ }^{54}$

De aspiranten waren niet verplicht, indien men het meesterschap te Gent wenste te verwerven, de opleiding in de Arteveldestad te doorlopen. Gent bleek immers, net zoals Doornik, hieromtrent een wederzijds akkoord te hebben met verschillende steden. ${ }^{55}$ Daarentegen gold wel de verplichting dat de leerlingen gedurende de opleiding inwoonden bij hun leermeester. Pas sinds de jaren 1770 was deze regel niet langer van kracht. ${ }^{56}$ De aspirant vormde dus een onderdeel van het huishouden van de meester, hij werkte bij de meester en indien hij niet gehoorzaamde kon hij er fysiek gestraft worden. ${ }^{57}$ Dit in acht genomen, samen met het feit dat een aspirant zijn opleiding diende te bekostigen, bleek het uiteraard voordeliger opgeleid te worden in een bekend milieu. Toch kan voor amper 5 individuen (Lieven Pietersz. Plumion, Hendrik van Cleve, Augustinus Cnudde, Nicolas de Liemakere en Pieter Norbert van Reijsschoot) met zekerheid gezegd worden dat ze door hun vader geschoold werden. Het lijkt mij echter duidelijk dat dit cijfer te laag is. Mondelinge afspraken bleken immers het algemene principe. Vader en zoon sloten met een eenvoudige handdruk contracten af. ${ }^{58}$ Een manifest gebrek aan bronnen- en bewijsmateriaal is hiervan het gevolg.

\subsection{Knechtschap}

$\mathrm{Na}$ het doorlopen van de leertijd beschikte de kunstenaar in spe over de vereiste vaardigheden voor het uitbouwen van een artistieke carrière. Zelfstandig werken bleek echter nog niet mogelijk. Het op eigen benen staan was namelijk uitdrukkelijk voorbehouden aan individuen die konden doorstoten naar het meesterschap. Dit lag echter niet binnen ieders mogelijkheden, net zoals trouwens niet elke leerling erin slaagde de leertijd tot een succesvol einde te brengen. ${ }^{59}$ Deze pupillen vielen dan ook uit de boot. Individuen die daarentegen wel de opleiding voltooiden, maar het meesterschap niet bereikten, hadden nog een toekomst in de corporatie. Tussen de leerjongen en de meester bestond immers een tussenstadium, de gezel

\footnotetext{
${ }^{50}$ I. H. VAN EEGHEN, De gilden: theorie en praktijk (Bussum, 1965), p. 24.

${ }^{51}$ DE JAGER, Meester, leerjongen, leertijd, p. 70.

${ }^{52}$ DE MUNCK, DENDOOVEN, Al doende leert men, p. 11.

53 A. HAUSER, Sociale geschiedenis van de kunst (Nijmegem, 1975), p. 267; G.M.A. DE WILDE, Geschiedenis onzer academiën van beeldende kunsten (Leuven, 1941), p. 41.

${ }^{54}$ H. MIEDEMA, "Kunstschilders, gilde en academie. Over het probleem van de emancipatie van de kunstschilders in de Noordelijke Nederlanden van de $16^{\mathrm{de}}$ en $17^{\mathrm{de}}$ eeuw", Oud Holland, 101 (1987, 1), pp. 20-21.

${ }^{55}$ VAN DER HAEGHEN, La corporation des peintres, pp. 285-286.

${ }^{56}$ SAG, Reeks 156 Algemene neringen, nr 3, 6, Ordonnanties rakende de neringen, corpora en gilden binnen Gent, 17e-18e eeuw.

${ }^{57}$ NORTH, Art and commerce, p. 66.

${ }^{58}$ DE MUNCK, DENDOOVEN, Al doende leert men, p. 14.

${ }^{59}$ VAN EEGHEN, De gilden, p. 24.
} 
of knecht ${ }^{60}$.

Twee redenen bieden een verklaring waarom vele gekwalificeerde arbeiders nooit het stadium van meester bereikten. Dit kwam omdat ze ofwel het nodige geld niet bij elkaar konden krijgen, ofwel omdat ze de verantwoordelijkheid niet wensten te dragen die de oprichting van een eigen bedrijf met zich meebracht. Zowel het vereiste startkapitaal als de vaste kosten waren immers zeer aanzienlijk. ${ }^{61}$ De handwerkers die zich economisch niet konden emanciperen, moesten zich tevreden stellen met het werken voor een ander tegen een loon. ${ }^{62}$ Eens voldoende geld gespaard en overtuigd van de eigen kwaliteiten was het nog steeds mogelijk om de stap naar het meesterschap te zetten.

\subsection{Meesterschap}

\subsubsection{Toelatingsvoorwaarden}

Het verwerven van het meesterschap werd beschouwd als het laatste stadium van de corporatieve vakopleiding. Na het behalen van de meestertitel was men in principe volleerd en behoorde het tot de mogelijkheden om een eigen zaak op te starten. ${ }^{63}$ Deze vrijheid in het ambacht verwierf men echter niet zomaar, ondanks de versoepelingen opgelegd door keizer Karel in 1540. Men moest nog steeds aan verschillende vereisten voldoen om meester te worden in de Sint-Lucasgilde te Gent. Men kon niet zomaar vrij het beroep uitoefenen en beschikken over een eigen atelier en winkel:

"Item dat eenijgelick wezende poortere van Ghendt, in de voors. neerijnghe zal moghen commen ende coopen de vrijheijt van diere, midts alvoren doende behoorlicke preuve ende betalende ten prouffijcte van der neeringhe in als zes Carolus guldenen alleenlijck, zonder dat zij vermoghen zullen ijet voordere t'exigierne onder 't dexele van proufghelde, maeltijde, noch anderssins in gheender manieren, up scheerpe correctie als boven. "64

Om vrijmeester te worden, moest men in de eerste plaats het Gents poorterschap bezitten. 57 meesters uit de populatie dienden zich dan ook in orde te stellen met dit voorschrift, aangezien met zekerheid gezegd kan worden dat ze niet van Gentse origine waren (77\% afkomstig uit de Zuidelijke Nederlanden, 18\% afkomstig uit het buitenland, 5\% onbekend). Van 25 van deze 57 meesters is gekend wanneer ze het poorterschap verwierven. In tabel 1 wordt dit jaartal vergeleken met het jaar van intrede in de Sint-Lucasgilde.

\begin{tabular}{|c|c|}
\hline Poorter $>$ Meester & 1 \\
\hline Poorter $=$ Meester & 19 \\
\hline Poorter $<$ Meester & 4 \\
\hline Onbekend & 1 \\
\hline
\end{tabular}

Tabel 1: vergelijking tussen de jaren van het verwerven van het poorterschap en de intrede in de Sint-Lucasgilde

Eén meester, de uit Bergen afkomstige Jan-Baptiste Balliu, werd eerst poorter van de stad

\footnotetext{
${ }^{60}$ In deze studie betreft het vrije knechten. Onvrije knechten hadden immers geen ambachtsopleiding gevolgd en waren derhalve geen lid van het ambacht.

${ }^{61}$ DAMBRUYNE, De Gentse bouwvakambachten, p. 64.

${ }^{62}$ G. DES MAREZ, L’organisation du travail à Bruxelles au XVe siècle (Brussel, 1904), p. 43.

${ }^{63}$ J.M. MONTIAS, Artists and artisans in Delft in the seventeenth century (New Haven, 1976), p. 17.

${ }^{64}$ SAG, Reeks 183-1, fol. $16 v^{\circ}$. Dit artikel komt overeen met het $73^{\text {ste }}$ artikel van de Concessio Carolina.
} 
Gent (1763) en pas het volgende jaar (1764) werd hij ingeschreven als huisschilder. Vier meesters zijn eerst terug te vinden in de registers van de Sint-Lucasgilde, alvorens genoteerd te worden in het Poortersboek. Dit betekende dat ze zonder Gents poorter te zijn toch toegang hadden tot het meesterschap. Vermoedelijk ontsnapten ze aan de aandacht van de controle. Zolang immers niemand nadeel ondervond van deze situatie, was vermoedelijk niemand zinnens om de bevoegde instanties hierop attent te maken. De overgrote meerderheid $(76 \%)$ werd echter meester en poorter in hetzelfde jaar. Dit houdt in dat ze reeds als gevormde kunstenaars verhuisden naar Gent. Opleiding kan dus niet de reden zijn waarom de meesters besloten te migreren naar Gent.

De toegang tot het meesterschap bleek bovendien ook een financiële kwestie. Men diende immers de vrijheid van het ambacht te kopen. In 1540 ging de keizer wel van het principe uit dat een aspirant-meester veeleer een bewijs van zijn technische vaardigheid moest leveren dan over een goedgevulde geldbeurs te beschikken. Daarom koppelde hij aan het behalen van de meestertitel het afleggen van een bekwaamheidproef (cfr. infra) en een eenmalig en uniform intredegeld van zes carolusgulden, wat overeenkwam met 240 gr. Vl. Dit was hoogstens één tiende van wat vroeger werd geëist. ${ }^{65}$ Dit bedrag voor de koop van het ambacht bleef tot het einde van het Ancien Régime ongewijzigd, met uitzondering van de periode van de Calvinistische Republiek. Bovendien behoorden de veelvuldige en hinderlijke rechten (proufghelde, maeltijde,...) die tot dan werden geheven, eveneens tot het verleden.

Daarenboven diende de aspirant-meester, indien hij de vrijheid van het meesterschap wenste te verwerven, nog een bewijs van zijn technische vaardigheid te leveren. Het afleggen van een behoorlicke preuve was immers een noodzakelijke voorwaarde om als meester aan de slag te kunnen. Hoewel de Carolijnse Concessie melding maakte van de meesterproef, leek het bewijs van bekwaamheid niet direct ingang te vinden in de Gentse ambachtswereld. In 1600 richtte de kunstenaarsnering immers een rekwest aan de schepenen van de keure. De nering klaagde aan dat de vakbekwaamheidproef al 16, 17 of 18 jaar, vermoedelijk dus sinds de val van de Calvinistische Republiek, niet meer werd onderhouden. Het ambacht argumenteerde dat dit resulteerde in het vervaardigen van slechte, onbehoorlijke werken, wat enorme schade met zich meebracht voor Gent, de hoofdstad van Vlaanderen. De corporatie verzocht dus de instelling van een degelijke kwalificatieproef. ${ }^{66}$ Op 18 oktober van hetzelfde jaar stelde het ambacht een reglementvoorstel op voor de meesterproef. De fijnschilders dienden een klein tafereel met naakte figuren of een landschap met geklede figuren te schilderen naar keuze van de gezworenen. Vergulders, stoffeerders en huisschilders ${ }^{67}$ behoorden een gesneden beeld te vergulden en te polychromeren. De sculpteurs hadden keuze uit drie verschillende toelatingsproeven. Ofwel vervaardigden ze een figuur, ofwel een grafzerk met een beeltenis, ofwel een verheven tombe. De meesterproef van de goudslagers werd niet nader omschreven. Er staat enkel dat de goudslagers zich dienden te schikken naar de ordonnantie van de schepenen met betrekking tot deze materie. Toch is de inhoud van de bekwaamheidsproef van de goudslagers gekend. Pieter Ameloot de Jonghe werd in 1665 opgetekend als meestergoudslager. Bovendien is geweten dat op 21 november van datzelfde jaar zijn meesterproef, bestaande uit het slaan van bladen goud, werd goedgekeurd. Het voorstel specificeert wel nog de kwalificatieproef van de glazenmakers. Ook deze groep had keuzemogelijkheden. De eerste optie was het vervaardigen van een glazen lantaarn. De andere mogelijkheden hielden in dat zij een "ouvalle gevoucht met eenen hellem, met zijn wapen ende wayeelen, ofte eenen teerlinck pandt" maakten. Zij hadden met andere woorden de keuze tussen een ovalen medaillon via de glas-in-loodtechniek met wapenschilden of een vierkant glasraam. ${ }^{68}$ Nadien

\footnotetext{
${ }^{65}$ DAMBRUYNE, De Gentse bouwvakambachten, p. 69.

${ }^{66}$ SAG, Reeks 183-1, fol. 50v ${ }^{\circ}$.

${ }^{67}$ Deze drie groepen werden niet bij naam genoemd in het reglement van 1600, in tegenstelling tot dit van 1657.

68 SAG, Reeks 183-1, fol. 51.
} 
bestond het proefstuk uit het vervaardigen van een glazen venster met overhoeks geplaatste ruitjes. ${ }^{69}$ Op 23 oktober 1600 bekrachtigden de schepenen van de keure het voorgestelde reglement van de nering en zij herinnerden er bovendien aan dat men in het bezit diende te zijn van het poorterschap van de stad indien men de vrijheid van het beroep wenste te verwerven. ${ }^{70}$ Het verzoek van het ambacht werd dus ingewilligd. In 1657 bekrachtigde de Gentse magistraat andermaal deze vakbekwaamheidproeven. Bovendien stipuleerde het ambachtsreglement van 1657 dat het proefstuk vakkundig werd gekeurd door drie examinatoren, met name de aftredende gezworenen en een glasblazer. ${ }^{71}$

Indien buitenstaanders probeerden het ambachtsmonopolie te breken, sloot men de rangen en ging men eendrachtig in de tegenaanval. De individuen die conform waren met de voorschriften lieten immers niet toe dat anderen dezelfde arbeid verrichtten, zonder in regel te zijn met de reglementeringen. De oversten en gezworenen hadden daartoe door het ambachtsreglement van 1542 inspectierecht verkregen. Ze beschikten bovendien over disciplinaire macht en het stond hen vrij de misbruiken aan de magistraat te signaleren. ${ }^{72}$ Dergelijke voorvallen vonden vaak hun neerslag in de rekeningen. Het ambacht deed immers beroep op gerechtsverantwoordelijken om mensen aan te manen en goederen en werken te laten aanslaan. In 1702 verdiende de officier Philips Penneman 56 gr. Vl. voor zijn optreden tegen een jongen die onrechtmatig een wagen schilderde. ${ }^{73}$ In 1718 betaalde de corporatie de officier Wauman, die vier glasramen en twee schilderijen had aangeslagen, gemaakt door onvrije personen. Een jaar later verkreeg een procureur een geldsom voor zijn optreden tegen Joseph Paleijs, een onvrije borduurwerker. ${ }^{74}$ Nog eens twee jaar later sloeg een officier verschillende gesneden lijsten en een Onze-Lieve-Vrouwebeeld aan. ${ }^{75}$ Ook op andere plaatsen is informatie te vinden betreffende personen die ten onrechte het ambacht beoefenden. In de schepenvonnissen van de keure voor het jaar 1689 is bijvoorbeeld een zaak terug te vinden tussen de nering en een zekere Breughel. Deze had de vrijheid van het ambacht niet verworven en diende dan ook een boete te betalen van 120 gr. Vl. Bovendien werd hem verder uitdrukkelijk verboden nog werken uit te voeren, waarvoor het lidmaatschap van het ambacht vereist was. ${ }^{76}$

\subsubsection{Kwantitatieve benadering}

Gedurende de periode 1574-1773 verwelkomde de gilde van Sint-Lucas niet minder dan 859 nieuwe meesters. 37 meesters $(4,31 \%)$ verkregen de toestemming om 2 professionele activiteiten uit te voeren. De twee meest voorkomende combinaties zijn glazenmakerstoffeerder (8) en stoffeerder-wasgieter (4). Opmerkelijk is dat amper vier van de 37 leden dubbel intredegeld betaalden. Het betreft Pieter de Graef (glazenmaker en huisschilder, 1721), Pieter Colman (beeldhouwer en stoffeerder, 1751), Dominicus Cruyt (beeldhouwer en stoffeerder, 1755) en Carel Hoentjens (glazenmaker en stoffeerder, 1755) ${ }^{77}$ Naar de reden is het gissen. Carel Hoentjens was namelijk maar één van de 8 meesters die toelating kreeg zowel als glazenmaker als stoffeerder actief te zijn. Grafiek 1 toont het aandeel van de verschillende professionele categorieën in het totale aantal inschrijvingen.

\footnotetext{
${ }^{69}$ SAG, Nota's van Werveke, 1169.

${ }^{70}$ SAG, Reeks 183-1, fol. 51v ${ }^{\circ}$.

${ }^{71}$ SAG, Reeks 183-3.

${ }^{72}$ SAG, Reeks $183-1$, fol. $16 v^{\circ}$

${ }^{73}$ SAG, Reeks 183-5, 1701-1706.

${ }^{74}$ SAG, Reeks 183-5, 1717-1719.

${ }^{75}$ SAG, Reeks 183-5, 1720-1724.

${ }^{76}$ VAN DER HAEGHEN, La corporation des peintres, p. 284.

${ }^{77}$ SAG, Reeks 183-5, 1720-1724, 1747-1751, 1753-1755.
} 


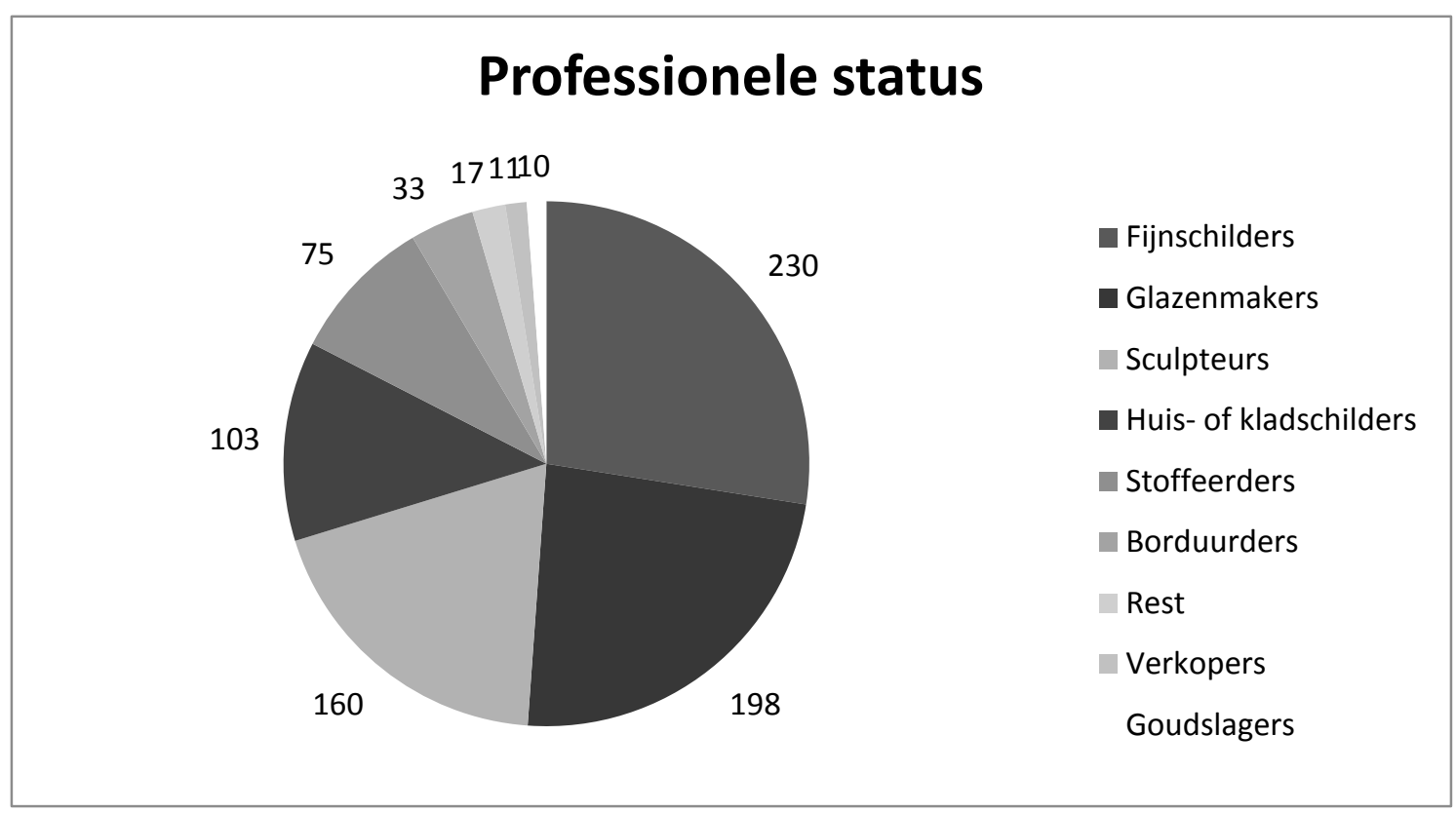

Grafiek 1: professionele status leden $(1574-1773)$

Het jaarlijks aantal inschrijvingen vertoont een onregelmatig verloop. Daarom biedt grafiek 2 een overzicht van het aantal inschrijvingen per decennium. Extreme jaarlijkse schommelingen gaan daarbij verloren, maar de trend is duidelijker.

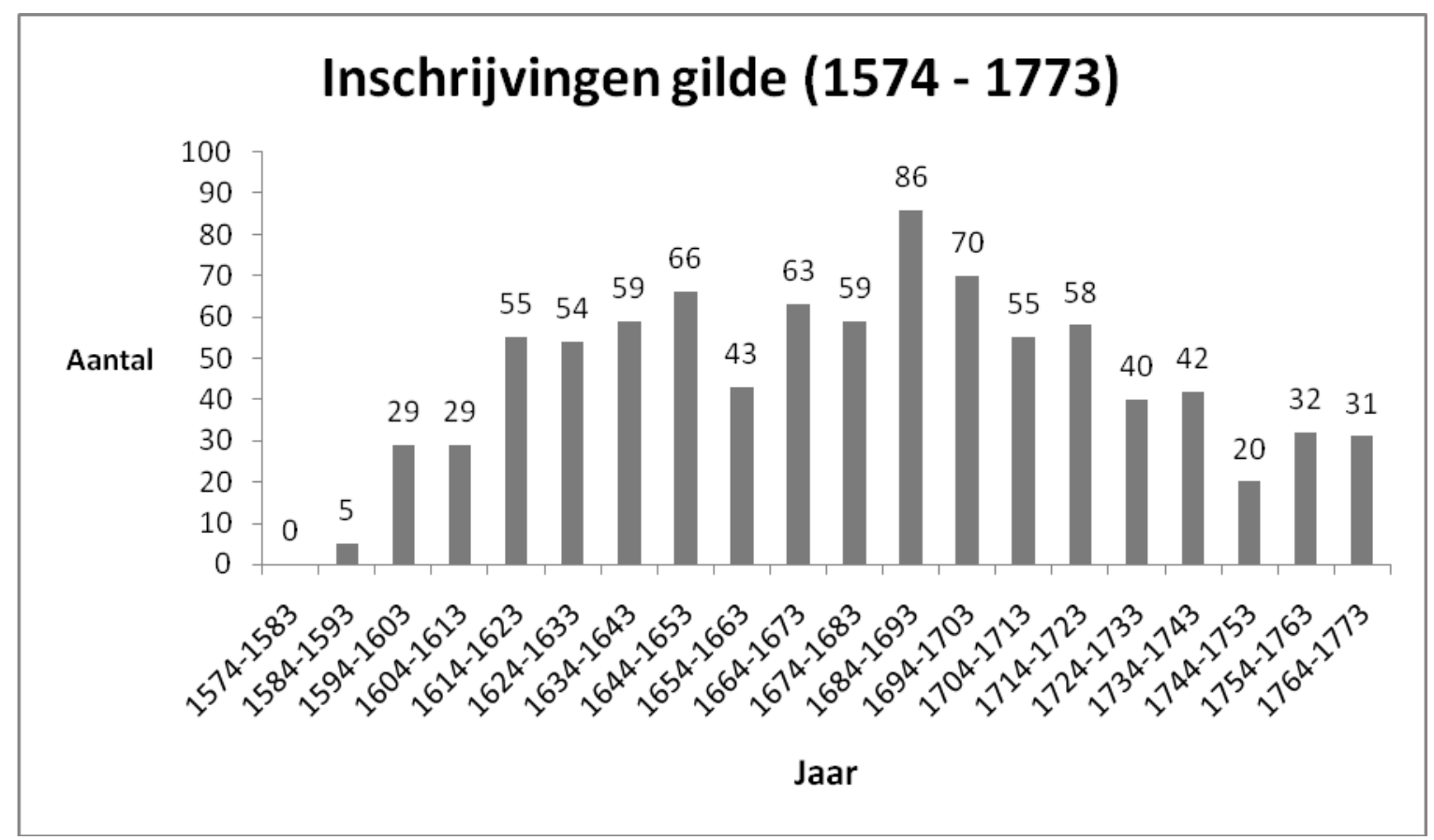

Grafiek 2: inschrijvingen gilde per decennium (1574 - 1773)

Het gemiddeld aantal inschrijvingen per jaar bedraagt bijna 4,5, wat neerkomt op 45 inschrijvingen per decennium. Grafiek 2 toont dat het effectieve aantal nieuwe leden afwijkt van dit gemiddelde. De lage vertegenwoordiging in de eerste decennia is heuristisch te verklaren. De kleiner aantallen gedurende het grootste deel van de $18^{\text {de }}$ eeuw daarentegen dient men te zien in het licht van de afscheiding van de huisschilders en borduurwerkers. Deze twee letten besloten immers hun eigen weg op te gaan. 
Deze gegevens zijn des te interessanter in contrast met deze van andere steden. Een vergelijking met Antwerpen dringt zich dan ook op. De Antwerpse Sint-Lucasgilde telde in de periode 1490-1530 545 nieuwe meesters. De vergelijking van verschillende tijdsperioden ligt niet echt voor de hand. Deze tijd (1490-1530) kenmerkte zich door de groei van de Antwerpse economie. Geld was overvloedig aanwezig en grondstoffen vonden makkelijk hun weg naar de Scheldestad. De aanwezigheid van financiële middelen zorgde eveneens voor het bestaan van een afzetmarkt voor kunst. Deze nieuwe rijkdom wekte dan ook de interesse van vele vakmannen. ${ }^{78}$ Een groter probleem is de verschillende samenstelling van de Gentse en Antwerpse Sint-Lucasgilde. Zoals blijkt uit grafiek 1 vertegenwoordigden de schilders, sculpteurs, glazenmakers en glasschilders de overgrote meerderheid van de leden. Samen zijn deze categorieën goed voor 588 nieuwe meesters of $65,63 \%$ van het totale aantal nieuwe meesters. Diezelfde groepen waren te Antwerpen in de periode 1490-1530 eveneens dominant. Onder de 545 inschrijvingen bleken er 217 schilders (geen huisschilders), 59 beeldsnijders en 54 glazenmakers en glasschilders te zijn, goed voor 330 meesters of $60,55 \%$. Enkel rekening houdend met deze drie groepen, betekent dit dat gedurende de periode 14901530 de Antwerpse gilde gemiddeld 82,5 nieuwe leden per decennium telde. Om een nuttige vergelijking met Gent mogelijk te maken, worden ook hier enkel deze groepen in rekening gebracht. Per decennium kende de Gentse gilde amper 29,4 inschrijvingen of nauwelijks meer dan $1 / 3$ van het aantal inschrijvingen bij het begin van de economische opgang van de stad Antwerpen.

Het is tot slot noodzakelijk ook het ongelijk aantal inwoners van de steden in rekening te brengen. Antwerpen telde omstreeks het begin van de $16^{\text {de }}$ eeuw 50000 à 55000 inwoners. Dit betekende dat 0,15 à $0,165 \%$ van de inwoners een professionele carrière in de kunstwereld (schilder, beeldsnijder, glazenmaker, glasschilder) beoogde. ${ }^{79}$

\begin{tabular}{|c|c|c|c|}
\hline Periode & Bevolkingscijfer $^{80}$ & Inschrijvingen $^{\text {Percentage }}$ \\
\hline \hline $1596-1605$ & \pm 29500 & 30 & $0,102 \%$ \\
\hline $1606-1615$ & 31073 & 23 & $0,074 \%$ \\
\hline $1616-1625$ & 37380 & 43 & $0,115 \%$ \\
\hline $1626-1635$ & 40797 & 33 & $0,081 \%$ \\
\hline $1636-1645$ & 43829 & 40 & $0,091 \%$ \\
\hline $1646-1655$ & 46059 & 38 & $0,083 \%$ \\
\hline $1656-1665$ & 49310 & 36 & $0,073 \%$ \\
\hline $1666-1675$ & 50680 & 38 & $0,075 \%$ \\
\hline $1676-1685$ & 51030 & 50 & $0,098 \%$ \\
\hline $1686-1695$ & 51887 & 54 & $0,104 \%$ \\
\hline
\end{tabular}

\footnotetext{
${ }^{78}$ F. VERMEYLEN, Painting for the market: commercialization of art in Antwerp's Golden Age (Turnhout, 2003), pp. 15-18.

${ }^{79}$ Gegevens met betrekking tot Antwerpen gehaald uit M.P.J. MARTENS, N. PEETERS, “Artists by Numbers: Quantifying artists' trades in 16th century Antwerp", in M. FARRIES (eds.), Making and Marketing: Studies of the Painting Process in Fifteenth- and Sixteenth-Century Netherlandisch Workshops (Turnhout, 2006), s.p.

${ }^{80}$ J. DAMBRUYNE, Economische conjunctuur en sociale structuren te Gent: 1590-1660: een kwantitatieve verkenning, Licentiaatverhandeling, Universiteit Gent (Gent, 1987), p. 151; DAMBRUYNE, Mensen en centen, pp. 349-351; P. DEPREZ, "Het Gentse bevolkingscijfer in de tweede helft van de $18^{\text {de }}$ eeuw", Handelingen van de Maatschappij voor Geschiedenis en Oudheidkunde te Gent, (1957), pp. 181-183.
} 


\begin{tabular}{|l|l|l|l|}
\hline $1696-1705$ & 51285 & 29 & $0,056 \%$ \\
\hline $1706-1715$ & 49781 & 31 & $0,062 \%$ \\
\hline $1716-1725$ & 44120 & 33 & $0,075 \%$ \\
\hline $1726-1735$ & 42732 & 23 & $0,054 \%$ \\
\hline $1736-1745$ & 44226 & 31 & $0,070 \%$ \\
\hline $1746-1755$ & 45400 & 21 & $0,046 \%$ \\
\hline $1756-1765$ & 43661 & 27 & $0,062 \%$ \\
\hline $1766-1775$ & 45465 & 20 & $0,044 \%$ \\
\hline
\end{tabular}

Tabel 2: percentage van de mensen te Gent in de $17^{\mathrm{de}}$ en $18^{\mathrm{de}}$ eeuw die een professionele carrière beoogden als schilder, sculpteur, glazenmaker of glasschilder

Indien de Gentse percentages uit tabel 2 vergeleken worden met het cijfer voor Antwerpen, blijkt al snel dat per duizend inwoners Antwerpen algemeen beschouwd dubbel zoveel kunstenaars telde als Gent. De Antwerpse situatie heeft daarenboven betrekking op de jaren 1490-1530, het begin van de bloeiperiode. Voor grosso modo de periode 1540-1585, het hoogtepunt van de bloei, zullen de cijfers ongetwijfeld nog hoger liggen. Gedurende die jaren kon Antwerpen immers met recht en reden getypeerd worden als een welvarend internationaal handelscentrum en reeds CarelVan Mander (1548-1606) wist ons te vertellen dat "de Const geern is by den rijckdom". 81

Het aantal inschrijvingen blijkt echter geen allesomvattend gegeven. Om bijvoorbeeld inzicht te krijgen in de concurrentie tussen de verschillende meesters, is het totale aantal actieve meesters per jaar een betere indicator. Om dit te bepalen is echter voor elke meester de datum nodig waarop hij kwam te overlijden of het ambacht verliet. Lid was men immers niet voor het leven. Men kon steeds het ambacht verlaten. Zo deed Anselmus Hebbelynck op 15 september 1663 afstand van de vrijheid van het ambacht van de schilders. De datum van overlijden is niet met zekerheid gekend, maar zeker is wel dat hij in 1674 nog in leven was. In dat jaar regelde hij, samen met zijn zoon Pieter, de erfenis van zijn overleden echtgenote.

Er bestaat echter een andere weg voor het bepalen van het aantal actieve meesters per jaar. De leden of suppoosten van het ambacht dienden immers jaarlijks de kas te spijzen via de betaling van lidgeld. Ook al voldeed een individu aan de toelatingsvoorwaarden van het ambacht, men diende jaarlijks zijn lidmaatschap te vernieuwen. Dit gebeurde dus door het betalen van een geldsom. Lid worden en blijven van het ambacht had dus financiële consequenties. Die jaarlijkse bijdrage, de ommestellinghe, is terug te vinden in de rekeningen. Pas vanaf het jaar 1682 is het echter duidelijk over hoeveel individuen of actieve meesters het daadwerkelijk gaat. Voordien is enkel het totale bedrag van de omstelling terug te vinden in de rekeningen. Grafiek 3 geeft een overzicht van het aantal actieve meesters per jaar en kent een gelijkaardig verloop als grafiek 2 .

\footnotetext{
${ }^{81}$ M.J. BOK, Vraag en aanbod op de Nederlandse kunstmarkt, 1580-1700, Doctoraatproefschrift, Universiteit Utrecht (Utrecht, 1994), p. 53.
} 


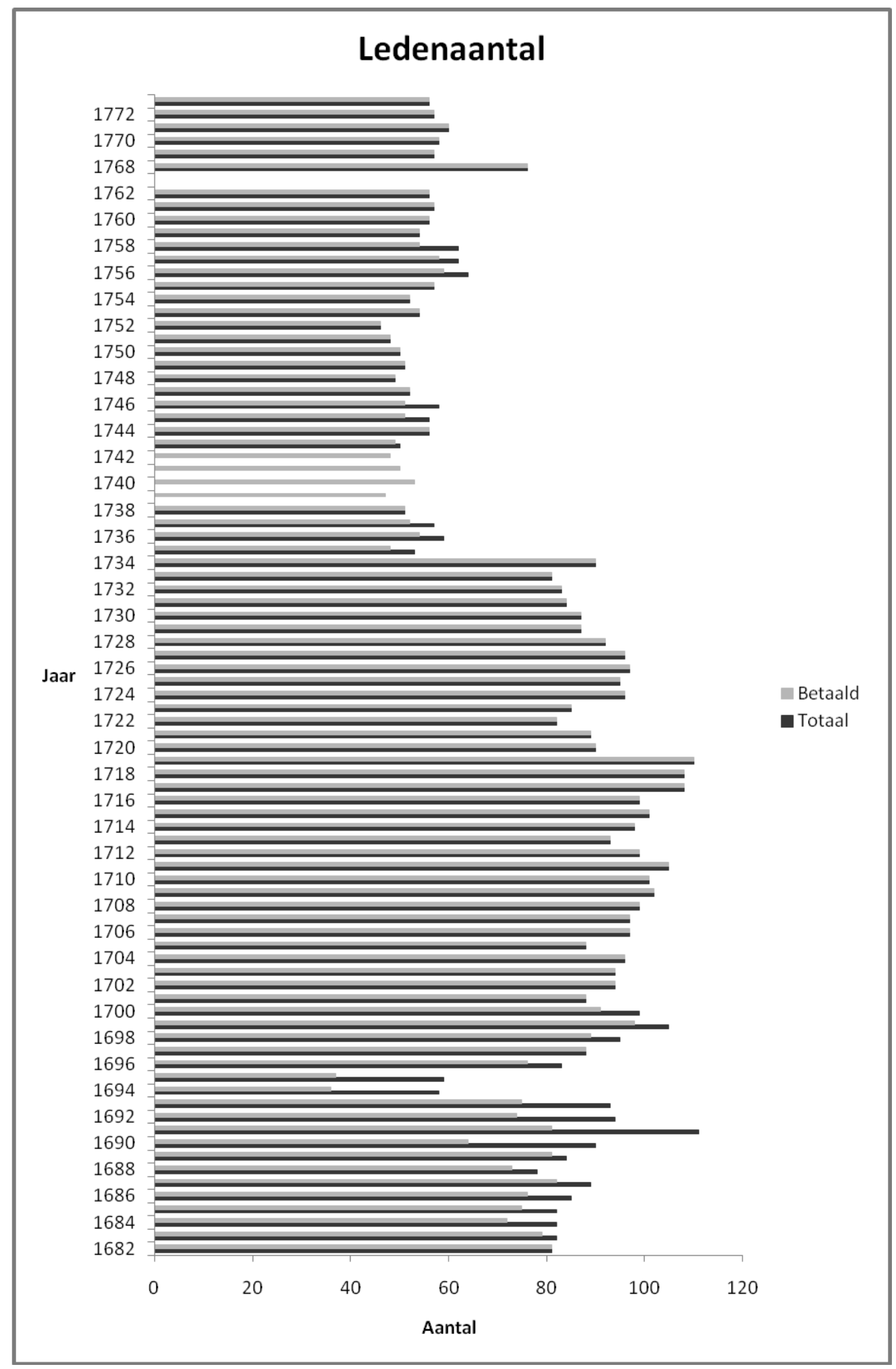

Grafiek 3: aantal actieve meesters $(1682-1773)$ 


\subsubsection{Profiel van de kunstenaar}

\subsubsection{Geslacht}

Individuen die het meesterschap bereikten waren van het mannelijke geslacht, aangezien vrouwen het beroep niet konden aanleren. De geschiedenis van de corporaties wordt namelijk gekenmerkt door een uitsluiting van vrouwen sinds de late middeleeuwen. Toch hadden gilden in vele vroegmoderne steden nog steeds een gemengd ledenbestand. ${ }^{82}$ Zo ook de Gentse Sint-Lucasgilde, waar een tiental vrouwen opdoken als meesteres, goed voor 1,16\% van het totale aantal nieuwe meesters. Een juffrouw Blazerijs is bovendien terug te vinden in de dubieuze lijst ${ }^{83}$ van de suppoosten van het jaar 1646. Vrouwen konden wel lid zijn van het ambacht indien ze getrouwd waren met wijlen een meester. Weduwen van meesters beschikten immers over een geprivilegieerde positie. Bij het overlijden van de echtgenoot hadden vrouwen de mogelijkheid om het meesterschap verder uit te oefenen. Dit recht behielden ze, zolang ze niet hertrouwden. ${ }^{84}$

Niet alle vrouwen die de professionele bezigheden van hun overleden echtgenoot continueerden, werden echter opgetekend als lid van de gilde. De weduwe van Ghijselbrecht Kerssavont ontving, net als haar overleden echtgenoot, betalingen voor verguldwerk. Zij staat echter nergens te boek als lid. Andere vrouwen verkozen het ambacht van hun overleden echtgenoot niet te continueren. Catherine de la Motte, weduwe van de fijnschilder Michiel Pijlsen, hield na de dood van haar man uitverkoop van zijn kunstobjecten en zijn verzamelde curiositeiten. Zij werd nooit opgetekend als lid van de gilde. Vermoedelijk probeerde ze door de uitverkoop nog een deel van het geïnvesteerde kapitaal terug te winnen.

\subsubsection{Kunstenaar in cijfers}

Reglementeringen in verband met de leeftijd waarop men het meesterschap kon verwerven, bestonden niet. Aangezien ook de beginleeftijd van de leerling, het aantal jaren opleiding en de tijd die men doorbracht als gezel op zijn minst onduidelijk is, is de intredeleeftijd een grote onbekende. Toch is het mogelijk van 74 individuen de leeftijd te bepalen waarop ze lid werden van de gilde. De uitkomst is dat de gemiddelde leeftijd bij het bereiken van het meesterschap 31 jaar was. Dit gemiddelde is echter te zeer beïnvloed door uiterste waarden. Zo trad bijvoorbeeld Gaspar de Crayer pas in op 82-jarige leeftijd. De op een na oudste meester was maar liefst 20 jaar jonger. Daarentegen bereikte Pieter (Francies) Maes het meesterschap volgens de bronnen op 12-jarige leeftijd. Pieter, geboren in het jaar 1753, betaalde in de periode 1763-1768 het lidgeld voor vier jaren. Dit betekent dat hij meester werd in het jaar 1765. Mogelijk betreft het hier evenwel een foutieve toeschrijving.

\begin{tabular}{|c|c|c|c|}
\hline Leeftijdscategorie & Aantal & Leeftijdscategorie & Aantal \\
\hline \hline$<20$ & 4 & $41-45$ & 3 \\
\hline $20-25$ & 19 & $46-50$ & 3 \\
\hline $26-30$ & 16 & $51-60$ & 2 \\
\hline $31-35$ & 19 & $60-80$ & 1 \\
\hline
\end{tabular}

\footnotetext{
${ }^{82}$ J.R. FARR, Artisans in Europe, 1300-1914 (Cambridge, 2000), p. 108.

${ }^{83}$ De betekenis van de lijst van de suppoosten van het jaar 1646 in het Schildersboeck is onduidelijk. Op de lijst komen namen voor van individuen die in 1646 het meesterschap nog niet hadden verworven. De mogelijkheid dat het leerlingen zou betreffen is weinig plausibel.

${ }^{84}$ DES MAREZ, L’organisation du travail à Bruxelles, p. 115.
} 


\begin{tabular}{|l|c|c|c|}
\hline $36-40$ & 6 & $>80$ & 1 \\
\hline
\end{tabular}

Tabel 3: leeftijd bij het verwerven van het meesterschap

De mediaan lijkt beter om de leeftijd van een intredend meester te bepalen, aangezien deze niet gevoelig is voor de uiterste waarden. De mediaan bedraagt 29 jaar en 6 maanden. Dit houdt in dat rond het $30^{\text {ste }}$ levensjaar de stap naar het meesterschap werd gezet. Op dat moment had men dus voldoende vertrouwen in het eigen potentieel en was men bereid de verantwoordelijkheid te dragen over een eigen atelier. Vroeger werd al gesteld dat het richtsnoer van 12 jaar om de opleiding te starten, steek kon houden. Afhankelijk van de duur van de leertijd (2, 4 of 6 jaar) betekent dit dat nieuwe meesters zonder probleem een decennium lang in loonarbeid bij andere meesters actief konden zijn. Gedurende deze periode kon men ervaring opdoen en geld sparen om uiteindelijk ook zelf de stap naar het meesterschap te zetten.

Het jaar van overlijden is gekend voor 90 individuen. Indien dit gegeven gecombineerd wordt met het jaar van intrede, is het mogelijk de duur van de carrière te bepalen. Er stelt zich echter een probleem. Men was geen lid voor het leven en men kon dan ook op elk moment de gilde de rug toekeren. Er is amper één individu bekend, Anselmus Hebbelynck, waarvan met zekerheid kan worden gezegd dat hij op het moment van overlijden geen lid meer was van de corporatie. Voor de overige 89 kunstenaars wordt het jaar van overlijden gelijkgesteld aan het laatste jaar lidmaatschap, ook als men niet meer in de stad aanwezig was. Vaak was men immers nog actief als kunstenaar na het verlaten van de Arteveldestad. De schilder Jan van Damme kan hier dienen als voorbeeld. In 1628 werd hij meester te Gent. In de periode 16281634 verliet hij de stad. Op 29 maart 1634 dook hij op als meester te Doornik, waar hij zijn carrière als kunstenaar vervolgde. De gemiddelde duur van een carrière bedroeg 30 jaar (en 3 maand). Ook hier spelen de uiterste waarden een grote rol. De loopbaan van Joos Neetesonne eindigde vooraleer die goed en wel begonnen was. Hij verwierf het meesterschap in het jaar 1701. Datzelfde jaar kwam hij te overlijden. De beeldsnijder Eustacius Eckmans had meer geluk. Na het verwerven van het meesterschap bleef hij nog 67 jaar in leven. Net als bij het bepalen van de leeftijd waarop men meester werd, lijkt ook hier de mediaan aangewezen. Deze bedraagt 32 jaar.

\subsubsection{Emigratie}

Eén van de bekendste migratiegolven is ongetwijfeld deze na de scheiding van de Zuidelijke en Noordelijke Nederlanden, te dateren in de jaren tachtig van de $16^{\text {de }}$ eeuw. Een groot deel van de intelligentsia uit het Zuiden zocht een onderkomen in het Noorden "om de wreetheyt van den constvyandigen mars te wijcken". De Verenigde Provinciën fungeerden als een toevluchtsoord voor vele Vlamingen die zich wegens hun politieke of religieuze overtuiging in eigen stad en land niet meer veilig wisten. ${ }^{85}$ Ongetwijfeld vertoefden onder de vele uitwijkelingen ook Gentenaars. Het bevolkingscijfer van de stad lag in 1590 niet minder dan 15000 eenheden lager dan een decennium eerder. Personen uit de populatie konden echter niet worden opgespoord.

Ook later trokken individuen weg uit Gent, naar bestemmingen in binnen- en buitenland. Van achttien Gentse meesters kan met zekerheid gezegd worden dat ze de stad hebben verlaten na het bereiken van het meesterschap. Sommigen keerden wel terug na enkele jaren. Tien personen bleven in het land (Antwerpen, Beveren, Brugge, Brussel, Doornik en Oudenaarde), zes personen trokken naar het buitenland (Amsterdam, Munster en Wenen, Paderborn, Parijs) en van 2 personen is de bestemming onbekend. Vijf van de achttien personen werden meester

\footnotetext{
${ }^{85}$ J. BRIELS, Vlaamse schilders in het Noorden in het begin van de Gouden Eeuw (Brussel, 1978), p. 5.
} 
in hun nieuwe verblijfplaats en één persoon, Lucas Flocket, keerde terug naar de stad waar hij als meester gekend was. Voor 3 personen is de directe aanleiding van de verhuis gekend. Laurentius Norbertus Heijlbroeck trok naar Brugge, waar hij benoemd was als muntgraveur. Anselmus Hebbelynck trok als hofschilder van Frederik Hendrik van Oranje in 1647 naar Munster om de aanwezigen op het Westfaalse vredescongres te portretteren. Daar borstelde hij meer dan 100 taferelen. Sommige bronnen spreken zelf van meer dan 400 werken. Bovendien makkten verschillende Duitse hoven van de gelegenheid en zijn aanwezigheid gebruik om bestellingen te plaatsen. $\mathrm{Na} 1647$ was Anselmus onder meer aanwezig in Nürnberg, Kassel en Dresden. In 1652 bevond hij zich in Wenen. Het volgende jaar vertoefde hij aan het hof te Gottorf, in opdracht van keizer Ferdinand III, die hem had opgenomen in de adelstand. Later dook Anselmus terug op te Gent. Ook de fijnschilder Nicolas de Liemakere vertoefde tijdelijk in het buitenland. Op verzoek van zijn vermoedelijke leermeester Otto Venius trok De Liemakere naar Paderborn, waar hij in dienst trad van Ferdinand II van Beieren, de prins-bisschop van Paderborn. Daar werd hij overladen met voordelen en bestellingen uit hoge kringen. De Liemakere kon echter niet aarden aan het klimaat en het hofleven, en keerde uit nostalgie terug naar zijn geboortestad Gent. Hij zou de stad niet meer verlaten. Er zijn te weinig gegevens om algemene uitspraken te doen, maar de voornaamste motivering voor buitenlandse migraties bij kunstenaars gedurende de vroegmoderne periode was inderdaad opdracht. ${ }^{86}$

\subsubsection{Dubbel lidmaatschap}

Het professionele leven van een individu hoefde zich niet te beperken tot één corporatie. Het was immers toegestaan lid te zijn van twee of meer ambachten, zodat eenzelfde persoon meerdere beroepen kon uitoefenen. Dit meervoudig lidmaatschap treft men vooral aan bij aanverwante ambachten en legde de meeste meesters geen windeieren. ${ }^{87}$ Het merendeel van de personen beperkte zich tot het lidmaatschap van één corporatie, 52 personen of $6,05 \%$ van het aantal meesters bezaten een dubbel lidmaatschap en één persoon had toelating om niet minder dan drie beroepen uit te oefenen. Artus van Roleghem verwierf in 1615 het meesterschap in de Sint-Lucasgilde. In $1627 \mathrm{kreeg}$ hij eveneens toestemming om als houtbreker actief te zijn. Nog eens drie jaar later bereikte hij ook het meesterschap bij de schrijnwerkers. De verschillende activiteiten van Artus speelden zich niet toevallig af binnen dezelfde sector, die van de houtbewerking. Tabel 4 biedt een overzicht in de tijd van het meervoudig meesterschap.

\begin{tabular}{|c|c|c|c|c|}
\hline $\begin{array}{c}\text { Professionele } \\
\text { status }\end{array}$ & $\begin{array}{c}\text { Totale aantal } \\
\text { vermeldingen }\end{array}$ & $\begin{array}{c}\text { Aantal } \\
\text { vermeldingen } \\
\mathbf{1 6}^{\mathbf{d e}} \text { eeuw }\end{array}$ & $\begin{array}{c}\text { Aantal } \\
\text { vermeldingen } \\
\mathbf{1 7}^{\mathbf{d e}} \text { eeuw }\end{array}$ & $\begin{array}{c}\text { Aantal } \\
\text { vermeldingen } \\
\mathbf{1 8}^{\text {de }} \text { eeuw }\end{array}$ \\
\hline \hline Steenhouwers & 31 & - & 20 & 11 \\
\hline Huisschilders & 12 & - & - & 12 \\
\hline Schrijnwerkers & 5 & - & 3 & 2 \\
\hline Houtbrekers & 3 & 1 & 2 & - \\
\hline
\end{tabular}

\footnotetext{
${ }^{86}$ W. BRULEZ, Cultuur en getal. Aspecten van de relatie economie-maatschappij-cultuur in Europa tussen 1400 en 1800 (Amsterdam, 1986), p. 43.

${ }^{87}$ DAMBRUYNE, De Gentse bouwvakambachten, p. 67.
} 


\begin{tabular}{|c|c|c|c|c|}
\hline Loodgieters & 1 & - & - & 1 \\
\hline Metselaars & 1 & - & 1 & - \\
\hline Kruideniers & 1 & - & 1 & - \\
\hline
\end{tabular}

Tabel 4: meervoudig lidmaatschap van de Gentse meesters in de tijd

31 Gentse meesters, allen ingeschreven in de Sint-Lucasgilde als beeldsnijder, beeldhouwer of steenhouwer, hadden ook het lidmaatschap van de steenhouwers verworven. Ze hadden de meesterproef van de steenhouwers met verve doorstaan. Deze bekwaamheidsproef bestond sinds 1600 enerzijds uit het vervaardigen van een console voor de dracht van een kruisgewelf en anderzijds uit een antieke schouw. ${ }^{88}$

Hoger werd al gewezen op het feit dat bepaalde meesters in de $17^{\text {de }}$ eeuw werden ingeschreven als steenhouwer in de Gentse Sint-Lucasgilde, zonder dat aantoonbaar is dat zij het meesterschap van de steenhouwers hadden verworven. Gedurende de $18^{\text {de }}$ eeuw bezaten de steenhouwers in de gilde wel het dubbel lidmaatschap. Ter verklaring is het versteningsproces gedurende de $17^{\text {de }}$ en de $18^{\text {de }}$ eeuw een mogelijke hypothese. De bouwnijverheid en de verfraaiingsector werden overladen met opdrachten. Voornamelijk gedurende de eerste drie kwart van de $17^{\text {de }}$ eeuw is die bouwactiviteit heel intens geweest. In de periode 1658-1664 werden bijvoorbeeld enkel in de huizenbouwsector 285 façaden gebouwd of hersteld. ${ }^{89}$ Deze bouwboom ontplooide zich niet enkel door particulieren. Er werden zowat 40 abdijen, kloosters en parochiekerken opgetrokken of gerestaureerd, allemaal met veel luister, als uiting van de triomf van de Contrareformatie. ${ }^{90}$ Net gedurende deze periode van uitgebreide constructiewerken doken de steenhouwers op in de Sint-Lucasgilde. Vermoedelijk was er zodanig veel werk dat geen enkele individu zich benadeeld voelde en de eventuele problemen aanklaagde. De onderlinge concurrentie zorgde niet voor conflicten, aangezien sculpteurs en steenhouwers hun handen vol hadden met werk.

In 12 gevallen combineerde men het lidmaatschap van het kunstenaarsambacht met dit van de huisschilders. Al deze gevallen zijn te dateren in de $18^{\text {de }}$ eeuw, meer bepaald na de afscheiding van de huisschilders (1735). Met het oog op werk, en dus inkomsten, bleek dit een interessante optie. De $18^{\mathrm{de}}$-eeuwse bouwstijlen kenden immers een grote plaats toe aan binnen- en buitenschilderwerk. Daarenboven werd de meesterproef bij de huisschilders in de loop van de $18^{\text {de }}$ eeuw afgeschaft, waardoor men de bekwaamheid niet eerst diende te demonstreren en dus gemakkelijk lid werd. Opmerkelijk is dat tweederden het lidmaatschap van de huisschilders combineerde met dit van de glazenmakers, waar men toch de (fijn)schilders zou verwachten.

De aanwezigheid van enkele schrijnwerkers is weinig opzienbarend. Het monopolie van de schrijnwerkers maakt dit duidelijk. Zij hadden het alleenrecht voor de fabricatie van slaapkoetsen, ledikanten, karossen, sneeuwsleden en andere rijtuigen, allerlei kasten, laden, schouwen, balustrades, versierde kruisen, schilderijlijsten, altaren, doksalen, predikstoelen, koor- en kapelportalen en -afsluitingen, biechtstoelen, communiebanken, antependia, tabernakels, koffers, allerlei tafels, lessenaars, alle soorten van lijsten om tapijten, goudleder en stoffen aan op te hangen, vogelkooien, persen, Spaanse stoelen en muziekinstrumenten. Deze voorwerpen stelden ook beeldsnijders geen onoverkomelijke problemen, net als de kwalificatieproef. Deze bestond sinds 1600 uit het timmeren van een dressoir, een ledikant of

\footnotetext{
${ }^{88}$ DAMBRUYNE, Het werkkader van de bouwsector, p. 131.

${ }^{89}$ V. FRIS, Histoire de Gand: depuis les origines jusqu'en 1913 (Gent, 1930), p. 240.

${ }^{90}$ J. DECAVELE, P. VAN PETEGHEM, "Zestiende en zeventiende eeuw" in J. DECAVELE (eds.), Gent. Apologie van een rebelse stad (Antwerpen-Gent, 1989), p. 128.
} 
een uittrekbare tafel. ${ }^{91}$ Het lidmaatschap van beide neringen kon enkel meer opdrachten met zich mee brengen en was dus financieel interessant, ook al had men verplichtingen in twee corporaties.

\subsubsection{Sociale netwerken}

De gilde had niet enkel een groot belang in de organisatie van de professionele activiteiten, maar het reguleerde eveneens het sociale, religieuze en culturele leven van de leden. Via het lidmaatschap van een gilde en via een eventuele bestuursfunctie, bereikte men een plaats op de sociale ladder. Een van de kernfuncties van de vroegmoderne ambachten was namelijk het construeren van distinctie en distantie. Er werd een tegenstelling gecreëerd tussen binnen en buiten, tussen de effectieve leden van het ambacht en de buitenstaanders. ${ }^{92}$ Bovendien haalde elke individuele gildebroeder uit zijn lidmaatschap een superieure status, die samenhing met zijn handvaardigheid. ${ }^{93}$

Door dit hechte netwerk kenden gildeleden elkaar persoonlijk. Samenwerking onder artiesten was dan ook geen onbekend gegeven. Victor Verspilt, gespecialiseerd in het schilderen van landschappen, stelde zijn artistieke kwaliteiten ter beschikking van Jan de Cleef. Cornelis Horenbault vervaardigde en schilderde glasramen voor de Sint-Martinuskerk te Ekkergem. Jacques Liemaekere (1618-1620) of Marten David (1624-1625) boden hierbij soms een helpende hand. Samenwerking diende ook niet steeds gelijktijdig te zijn. In 1682 tekende Gerij Pick het ontwerp voor een tabernakel, naar een schets van Jacques Pieters. Eén jaar later startte Pieters de uitvoering van het ontwerp. Nog eens twee jaar later werd het werk voltooid door Joannes van den Steene. Bepaalde professionele groepen dienden steeds samen te werken. Glasschilders werkten bijvoorbeeld naar een schets van een schilder op paneel of doek. Hij was dus meer technicus dan kunstenaar, meer vakman dan schepper, maar om de schets na te bootsen diende hij wel een vaardig tekenaar te zijn. ${ }^{94}$ Nicolas de Liemakere ontving bijvoorbeeld 8160 gr. Vl. voor het patroon van de ramen voor Sint-Baafs (1629). Het werk werd uitgevoerd door zijn vader Jacques. Het atelier van een meester kan dan ook niet beschouwd worden als een streng afgelijnd geheel, losstaand van een ander atelier. Contacten tussen ateliers kwamen veelvuldig voor. Bij het keuren van de kwaliteit van uitgevoerde werken vonden eveneens ontmoetingen plaats. Pick beoordeelde samen met Rombaut Pauwli het praalgraf van d'Alamont, uitgevoerd door de Luikenaar Jean Delcour. Wanneer Joannes van Volxsom in 1728 het werk De huldiging van keizer Karel VI als graaf van Vlaanderen door markies de Prié, op de Vrijdagsmarkt, de $18^{\text {de }}$ oktober 1717 voltooide, werd het tafereel gekeurd en "weerdich bevonden" door Ignatius de Becker en Hendrik Matthijs. Het werk werd geschat op 260000 gr. Vl. Van Volxsom verdiende 76000 gr. Vl.

De sterkte van de sociale banden tussen kunstenaars blijkt nog meer uit hun onderlinge relaties los van hun professionele bezigheden. Verwantschap tussen kunstenaars kwam veelvuldig voor. Jan-Baptiste van Helderbergh was verwant met de beeldhouwers Pieter de Sutter en Pieter-Antoon Verschaffelt. Kunstenaars trouwden ook met elkaar. Jacobus de Rinck huwde Peternelle Mehieut. Beiden waren actief in de borduursector. Niet enkel kunstenaars zelf, ook hun kinderen huwden individuen uit het milieu. Frans Pilsen huwde bijvoorbeeld op 2 april 1736 Marie Françoise de Rinck, dochter van de borduurder Jacobus. Kunstenaars namen ook het peterschap waar van kinderen van kunstenaars. Jeanne Marie Hebbelynck, dochter van Anselmus en Livina van den Tuyne had als peter de fijnschilder Nicolas de Liemakere. De peter van Rombaut le Plat, zoon van Pieter en Maria van

\footnotetext{
${ }^{91}$ DAMBRUYNE, Het werkkader van de bouwsector, p. 133, 135.

${ }^{92}$ DE MUNCK, DENDOOVEN, Al doende leert men, p. 43.

${ }^{93}$ DE MUNCK, DENDOOVEN, Al doende leert men, p. 44.

${ }^{94}$ SAG, Nota's van Werveke 587.
} 
Wachelgem, was niemand minder dan de beeldhouwer Rombaut Pauwli.

Naast contacten op familiale basis, sloten kunstenaars ook akkoorden met elkaar. Philips Schoof verkreeg op 12 september 1618 een volmacht van Lucas Flocket om diens huis te verkopen. Flocket was immers al in 1615 teruggekeerd naar zijn geboortestad Antwerpen.

Opmerkelijk is ook dat, hoewel kunstenaars verspreid leefden over de Gentse stad, er toch een concentratie van fijnschilders is op te merken in de buurt afgebakend door de Korenmarkt, de Vrijdagmarkt, de Sint-Baafskathedraal en de Sint-Jacobskerk. De woonplaats is weliswaar beschikbaar voor amper 37 individuen of $4,31 \%$, maar een trend wordt reeds gezet.

Het reconstrueren van sociale netwerken tussen kunstenaars is geen eenvoudige opdracht. Het bronnenmateriaal is immers verspreid en enkel fragmentarisch aanwezig. Duidelijk is wel dat professionele banden, familie en woonbuurt een bijdrage leverden in het vestigen en het consolideren van de positie van de kunstenaar in de maatschappij en op de markt. In tijden van economische groei fungeerden zij als een drager van sociale mobiliteit, in tijden van crisis als een vangnet. ${ }^{95}$

\subsubsection{Economische positie van de kunstenaar}

De sociale positie van een individu in de vroegmoderne maatschappij was nauw verbonden met zijn economische positie. Financiële mogelijkheden bepaalden in niet geringe mate de plaats op de maatschappelijke ladder. Deze economische positie van de kunstenaar bepalen is echter een hachelijke onderneming. De beste indicator voor de schatting van de rijkdom en aldus de relatieve economische status van de verschillende groepen burgers, en dus ook kunstenaars, lijkt mij de prijs van het huis dat zij kochten en verkochten. Helaas bracht archiefonderzoek deze gegevens slechts zelden aan het licht. Een andere mogelijkheid is het gebruik van gegevens met betrekking tot de erfenis. Hierbij stelde zich het probleem dat de erfenis van individuen bij hun dood een minder betrouwbare indicator is. De gestorvene was mogelijk niet meer actief of reeds verarmd op het moment van overlijden. Archiefonderzoek liet wel toe het prijskaartje van een resem werken te achterhalen. Het inkomen, en dus onrechtstreeks ook de welvaart, van kunstenaars kon dus - deels - worden gereconstrueerd. Lonen en prijzen geven immers inzicht in de economische positie van een bepaald individu. Belangrijk hierbij is dat men rekening dient te houden met de diversiteit binnen de professionele groep van de kunstenaars, enerzijds tussen de verschillende beroepen en anderzijds tussen beoefenaars van eenzelfde beroep.

Dé economische positie van dé kunstenaar bepalen is dan ook niet meer dan een utopie. De prijzen van (kunst)werken zijn immers afhankelijk van verschillende factoren die in het licht van deze studie uiteraard niet allemaal bepaald konden worden. Men denkt hierbij aan de grootte van het werk, het gebruikte materiaal, het niveau van de uitvoering, etc., maar ook aan zaken als de naambekendheid van de uitvoerder gedurende de vroegmoderne periode. Desondanks is het mogelijk enkele aspecten van de economische praktijken van kunstenaars naderbij te bekijken. De vele verschillen sluiten gemeenschappelijke kenmerken niet uit.

Hoewel ambachtsmeesters de toelating hadden om werken te vervaardigen, blijft de centrale vraag natuurlijk of er een afzetmarkt aanwezig was. Los van het antwoord op deze vraag, dient men daarenboven rekening te houden met de verschillende professionele status van de leden van het ambacht. Huisschilders en glazenmakers brachten hun arbeid niet op dezelfde manier aan de man als de schilder of beeldsnijder, hoewel beide groepen verfraaiingswerken uitvoerden. Huisschilders hadden geen nood aan een atelier of winkelruimte, hooguit een opslagplaats voor het materiaal. Men ging bij de klant aan huis en voerde daar zijn job uit. In wat volgt wens ik echter dieper in te gaan op de kunstmarkt, de markt voor luxeproducten.

\footnotetext{
95 M.P.J. MARTENS, “Antwerp Painters: their Market and Networks”, in Jaarboek Koninklijk Museum voor
} Schone Kunsten Antwerpen 2004/05 (Wommelgem, 2006), p. 73. 
De vraag naar luxeproducten, en dus ook kunstwerken, steeg gedurende de vroegmoderne periode, voornamelijk in de stadscentra van West-Europa. Eén van de logische voorwaarden was de beschikbaarheid van kapitaal. Dit diende echter geen astronomische proporties aan te nemen. Wanneer Philippe Lambert Joseph Spruijt twee schilderijen borstelde voor de Gentse schuttersvereniging betaalde elk geportretteerd lid 168 gr. Vl. Jacques Cockx sneed een beeld van Onze Lieve Vrouw (1636) voor 240 gr. Vl., niet meer dan het inschrijvingsgeld om het meesterschap te verwerven. Cornelis Horenbault schilderde het werk De Heilige Bartholomeus (1621) voor de corporatie van de huidevetters voor 120 gr. Vl. Voor een deel van de maatschappij was deze financiële drempel een onoverkomelijke hindernis, maar studies met betrekking tot kunstverzamelingen gedurende de vroegmoderne periode tonen duidelijk aan dat er een uitgebreid koperspubliek voor kunst aanwezig was in de stad Gent. Reeds Marcus van Vaernewijck (1518-1569) getuigde dat omstreeks het midden van de $16^{\text {de }}$ eeuw in menig poorterwoningen excellente voorwerpen aanwezig waren. Ongetwijfeld betrof het onder meer kunstwerken. ${ }^{96}$ Omstreeks 1660 werd over Antwerpen gezegd dat "il n'est point de maison où l'on ne voye quantité de fort beaux tableaux". Er werd zeer veel besteld en zeer veel aangekocht door mensen uit verschillende sociale lagen. ${ }^{97}$ De prijzen in de Antwerpse kunsthandel van de $17^{\text {de }}$ eeuw waren van die aard, dat het duidelijk is dat de middenklasse zich in ieder geval goedkopere werken kon aanschaffen. ${ }^{98}$ De middenlaag van de bevolking nam niet enkel deel aan de kunstmarkt in grote centra, zoals Antwerpen en de Hollandse hoofdsteden. Kleinschalige en perifere steden vertoonden een gelijkaardig patroon in kunstbezit als Antwerpen. ${ }^{99}$ Gent was Antwerpen niet, maar er is geen reden om aan te nemen dat in de Arteveldestad de situatie erg anders zou zijn. Waarmee niet gezegd wordt dat de kunstmarkt in beide steden op dezelfde schaal functioneerde. Naast de plaatselijke afzetmarkt, produceerde men ook voor het buitenland. Frankrijk (Parijs, Rijsel en Rouen) was gedurende de $18^{\text {de }}$ eeuw wellicht het voornaamste afzetgebied voor de Vlaamse kunstproductie, maar er ontspon zich ook een drukke handel met Rotterdam en 's-Gravenhage in het Noorden. Op het einde van de $18^{\text {de }}$ eeuw verschenen ook de eerste Engelse kunsthandelaars op het vasteland, om er kunstwerken te kopen. ${ }^{100}$

\subsubsection{Afzetmogelijkheden}

Kunstenaars probeerden, zoals alle ambachtslieden, de producten van hun arbeid aan de man te brengen. Hiervoor was de kunstmarkt de plaats bij uitstek. Dit was de economische ruimte waarin kunstwerken worden getransfereerd van de producent naar de consument, zowel direct als via een tussenpersoon (handelaar). In deze omgeving kon de koper de opdracht geven tot het maken van een kunstwerk of hij kon het werk kopen op de vrije, open markt. Het is echter noodzakelijk een onderscheid te maken tussen verschillende kunstmarkten. Er bestond een markt voor "kunst met de grote K" en dus hoge kwaliteit en dure voorwerpen. Daartegenover had men ook de markt voor goedkopere werken. Het eerste type bestond bijna uitsluitend in functie van de opdrachten van lokale en buitenlandse elites en instituties, terwijl het tweede type werd overspoeld door seriële producten voor verkoop op de vrije markt. Het cliënteel op dit tweede type markten was sociaal gediversifieerd. Het belang van dit tweede type mag

\footnotetext{
${ }^{96}$ E. DUVERGER, “Gentse kunstverzamelingen voor 1797”, in J. DECAVELE, R. VAN DE WALLE (eds.), De beurs van Judocus Vijdt (Sint-Niklaas, 1998), p. 37.

${ }^{97}$ DUVERGER, Kunstgeschiedenis der Nederlanden, p. 14.

${ }^{98}$ BRULEZ, Cultuur en getal, p. 68.

${ }^{99}$ B. BLONDE, V. DE LAET, "Owning paintings and changes in consumer preferences in the Low Countries, seventeenth-eighteenth centuries", in N. DE MARCHI, H.J. VAN MIEGROET (eds.), Mapping markets for Paintings in Europe, 1450-1750 (Turnhout, 2006), p. 103.

100 DUVERGER, Gentse kunstverzamelingen voor 1797, p. 55; DUVERGER, Kunstgeschiedenis der Nederlanden, p. 21.
} 
trouwens niet worden geminimaliseerd. Lorne Campbell stelde immers dat "...probably a small proportion of pictures were commissioned in the Southern Netherlands". ${ }^{101}$

Verschillende argumenten kunnen worden aangehaald om aan te tonen dat kunstenaars behoorden tot de groep van personen die men omschreef als winkeliers. Het corporatieve reglement van 1657 vermeldde uitdrukkelijk dat "... niemant en zal vermoghen te weercken ofte wijnckel te stellen, ten zij eerst vercreghen hebbende den vrijdom der zelver neerijnghe...". ${ }^{102}$ De meesters worden dus verbonden met een winkel, hoewel nergens uitdrukkelijk vermeld staat dat men verplicht een winkel diende te hebben. Men kan zich afvragen hoe een meester zijn werken aan de man bracht en overleefde, indien hij geen winkel had. Opdrachtgeving en bestellingen behoorden zeker tot de mogelijkheden, maar dan nog is het niet meer dan logisch dat potentiële klanten enkele staaltjes van het kunnen van de meester eerst konden aanschouwen. En waar kon dit beter dan in zijn winkel. Bovendien is er een tweede argument om aan te tonen dat kunstenaars onder normale omstandigheden een winkel uitbaatten. Zoals eerder aangehaald diende men jaarlijks een som geld, de omstelling, te betalen ten gunste van de corporatie. Bepaalde individuen werden vrijgesteld van deze verplichting onder uitzonderlijke omstandigheden. Eén van deze redenen is terug te vinden in de rekeningen van de jaren 1691-1693. Geroen de Snock betaalde geen lidgeld voor het jaar 1691, met als reden "zonder wynckel". ${ }^{103}$ Het is dus mogelijk te besluiten dat een kunstenaar per definitie een winkel ter zijn beschikking had, en aldus als winkelier omschreven kan worden. Ook Vermeylen concludeerde trouwens op basis van boedelinventarissen dat kunstenaars vaak op de benedenverdieping van hun woning een winkel hadden geïnstalleerd. ${ }^{104}$ Kunstenaars werkten inderdaad vanaf de $15^{\text {de }}$ eeuw op voorraad. Wat ze voortbrachten werd tentoongesteld in hun winkel of in andere kamers van de woning. Het gebruik van die winkels en vitrines werd vaak streng gereglementeerd door het kunstenaarsambacht, wat wijst op het belang dat men eraan hechtte. ${ }^{105}$ Voor Gent zijn hieromtrent geen reglementen bewaard. Bepaalde kunstenaars stalden hun werken uit op bruggen en openbare plaatsen. De Gentse schilders boden bijvoorbeeld hun werken te koop aan op 1 januari in de buurt van de Sint-Baafskathedraal en op het Veerleplein op 4 januari, het naamfeest van de Heilige Veerle. ${ }^{106}$ Potentiële kopers konden op deze plaatsen op zoek gaan naar het werk van hun voorkeur. Deze economische activiteiten situeerden zich op het tweede type kunstmarkt. Het grote probleem hierbij is een gebrek aan bronnenmateriaal. Indien kunstenaars uit de populatie al een zakelijke boekhouding opstelden, is deze in geen enkel geval bewaard. De omvang van deze verkoopmogelijkheid is dus niet te bepalen. Ook prijzen zijn een grote onbekende. De situatie op de jaarmarkten is daarentegen beter gekend.

Kunstenaars, voornamelijk schilders, trokken in de vroegmoderne periode van de ene naar de andere stad om op de vrije markt, "de foor", hun waren te koop aan te bieden. ${ }^{107}$ Zo ook te Gent. Op 13 oktober 1453, enkele maanden na de Slag bij Gavere, stond Filips de Goede de Gentenaars toe om gedurende zeven jaar twee jaarmarkten te houden. Beide jaarmarkten duurden 15 dagen. De ene begon op de maandag na de zondag waarop men de Oculi zong, namelijk de derde zondag van de vasten, de andere op de maandag na het feest op 1 augustus van de Heilige Pieter. Reeds het volgende jaar stemde de hertog toe om de toegangsrechten en accijnzen gedurende beide marktperiodes te verlagen. Een traditie was geboren. De licentie van de jaarmarkten werd op geregelde tijdstippen hernieuwd en uiteindelijk, in december

\footnotetext{
${ }^{101}$ VERMEYLEN, Painting for the market, pp. 6-7.

${ }^{102}$ SAG, Reeks 183-3.

103 SAG, Reeks 183-5, 1691-1693.

${ }^{104}$ VERMEYLEN, Painting for the market, p. 9.

${ }^{105}$ M.P.J. MARTENS, "De cliënteel van de kunstenaar”, in R. VAN SCHOUTE, B. DE PATOUL (eds.), De Vlaamse Primitieven (Leuven, 1994), p. 174.

106 SAG, Nota's van Werveke 587.

${ }^{107}$ SAG, Nota's van Werveke 587.
} 
1497, kende Filips de Schone een eeuwigdurend octrooi toe aan de halfvastenjaarmarkt, de belangrijkste van beide. ${ }^{108}$ Voor de kunstenaars bleek 1761 het einde van deze traditie. Zij werden voortaan niet meer vermeld naast andere kramers in de stadsrekeningen. ${ }^{109}$ Vrij snel echter na het verdwijnen van de kunstenaars op de halfvastenjaarmarkt vond het fenomeen van de kunsttentoonstellingen ingang in de stad. Het eerste kunstsalon vond plaats op het stadhuis in mei 1792 onder de titel "De beginselen der teekenkonst". De aanwezigheid van individuen als Philippe Lambert Joseph Spruijt en Pieter Norbert van Reijsschoot in het inrichtingscomité toont mooi aan dat deze tentoonstelling geïnspireerd werd vanuit de "academische" wereld.

Kunstenaars en kooplieden allerhande, zowel vreemdelingen als Gentenaars, boden op de vrije markt met halfvasten hun waren te koop aan. Vreemde kooplieden konden producten aan de man brengen, zelfs als die in Gent zelf werden vervaardigd. Buiten de jaarmarkt was het echter niet toegelaten om vreemde, niet-Gentse producten in de stad aan te bieden en te verkopen. ${ }^{110}$ Voor het kunstenaarsambacht betekende dit voorrecht dat men buiten de periodes van de jaarmarkten geen buitenlandse, of beter "buitenstedelijke" concurrentie hoefde te vrezen.

Ondanks de duidelijke reglementering probeerden niet-Gentenaars gedurende de bestaansgeschiedenis van de halfvastenjaarmarkt de afspraken te omzeilen. De eerste gedocumenteerde pogingen dateren al uit 1575. Vier personen uit Mechelen hadden, buiten de periode van de halfvastenjaarmarkt, schilderijen en beeldhouwwerken in een loterij gebracht te Gent. Het ambacht tolereerde dit niet en reageerde. Het bestuur van de corporatie sprak de stedelijke magistraat aan en deze verbond zich ertoe een reglement uit te vaardigen met betrekking tot de betreffende loterijen. De Mechelaars dienden bovendien hun praktijken stop te zetten. ${ }^{111}$ Het hoefde echter niet steeds tot problemen te leiden. Wanneer Johan Haecx, een handelaar uit Antwerpen, in 1615 met een grote partij dure Antwerpse schilderijen neerstreek te Gent, vroeg hij toestemming om deze aan de man te brengen. Hij hoopte de werken 14 à 15 dagen publiekelijk te kunnen tonen en hij was zelfs bereid om hiervoor te betalen. De schepenen, het idee genegen, legden het verzoekschrift voor aan de gezworenen van de SintLucasgilde. Hun antwoord was weinig verrassend. Haecx diende geduld te oefenen tot de halfvastenjaarmarkt. ${ }^{112}$ Het spel werd echter niet door iedereen even fair gespeeld en op regelmatige tijdstippen staken nieuwe problemen de kop op.

Net als in het geval van de winkels kan ook hier toegevoegd worden dat, indien men al een boekhouding bijhield gedurende de jaarmarkt, deze niet is bewaard. Vermoedelijk, door de aanwezigheid van vele kraampjes en dus de concurrentieslag, visiteerde een ruim koperspubliek deze jaarmarkten en werd er wel wat verkocht. Bovendien was het op de jaarmarkt ook mogelijk werken te presenteren aan het publiek. Overtuigd van het potentieel van een kunstenaar was het op deze wijze mogelijk bestellingen in de wacht te slepen.

Dergelijke orders komen overeen met het eerste type kunstmarkt uit de inleiding. Op 11 december 1619 bijvoorbeeld plaatste de kasselrij van Oudburg een bestelling bij Gaspar de Crayer voor het tafereel Het oordeel van Salomon. Op 11 januari 1620 werd de voorstudie goedgekeurd na het aanbrengen van enkele veranderingen op verzoek van de opdrachtgevers. Op 22 januari ondertekende De Crayer het contract. Diezelfde De Crayer vervaardigde, samen met François Duchatel, het werk De geloofsbelijdenis van de H. Norbertus en de broeders van zijn orde tijdens de kerstnacht van het jaar 1120 voor de abdij van Averbode. Een brief uit het jaar 1654 gaf enkele iconografische problemen weer die de schilder diende op te lossen. Deze

\footnotetext{
${ }^{108}$ VAN DER HAEGHEN, La corporation des peintres, pp. 332-333.

${ }^{109}$ SAG, Nota's van Werveke 587.

${ }^{110}$ SAG, Nota's van Werveke 980, Schilders op de foor.

${ }^{111}$ SAG, Reeks 183-1, fol. 19-21 vº.

${ }^{112}$ SAG, Reeks 183-1, fol. 41.
} 
eenvoudige voorbeelden geven de aanzet voor de verklaring waarom bestellingen in de literatuur steevast een grote rol toebedeeld krijgen. In tegenstelling tot werken die in de winkel van een kunstenaar of op een jaarmarkt worden gekocht, ging met bestellingen onderhandelingen gepaard. Vaak werden deze ook op papier gezet en bleven ze bewaard. Aangezien historici zich steeds dienen te baseren op de bronnen, is het niet meer dan logisch dat bestellingen de nodige aandacht kregen. Bovendien was het soms mogelijk om de vaak complexe ontstaansgeschiedenis van werken bloot te leggen. Algemeen beschouwd zijn stukken op bestellingen voor historici dus interessantere studieobjecten dan werken die verkocht worden op de anonieme markt. Daardoor lijkt het alsof de meerderheid van de werken op bestelling werd gemaakt. Niets is minder waar. Slechts een klein aandeel van de kunstwerken werd op bestelling vervaardigd. Het bronnenmateriaal is echter ontoereikend om dit aandeel nader te preciseren.

Bepaalde groepen die ressorteerden onder het ambacht werkten evenwel op bestelling. Toch kunnen ze niet ingepast worden in de kunstmarkt die hier centraal staat, met name de markt die wordt gedomineerd door opdrachten van lokale en buitenlandse elites en instituties. Het betreft bijvoorbeeld de huisschilders. Aan het schilderen van poorten, deuren, vensters en gevels ging steeds een opdracht vooraf. Wanneer de huisschilder François van Arschot in 1753 een koets olieverfde, was dit op bestelling. Jan van der Vinck schilderde in de jaren 1662-1665 de tussenwanden naast het hoogaltaar in de Sint-Jacobskerk te Gent. Een specifieke opdracht ging hieraan vooraf. Huisschilders werkten niet op voorraad en hadden weinig baat bij een winkel. Ze dienden er enkel voor te zorgen dat ze een zekere naambekendheid verwierven, waaruit voortvloeide dat klanten hen konden aanspreken. In grote mate geldt dit procedé ook voor glazenmakers. Glazeniers hadden vermoedelijk wel een voorraad glas liggen, maar het was toch wachten op een order van de klant. Afhankelijk van wat deze bestelde konden zij aan het werk. Passchier Galle leverde bijvoorbeeld 11 nieuwe vensters voor de Augustijnenkerk te Gent in de periode 1621-1631. Dit leverde hem 5400 gr. Vl. op. In het laatste kwart van de $17^{\text {de }}$ eeuw leverde François van Bommele glasramen aan de Sint-Sebastiaansgilde. Glazenmakers (en huisschilders) konden wel actief zijn op de kunstmarkt. Zo ontving Jan Heijlbroeck bijvoorbeeld op 20 november 16712208 gr. Vl. van Sebastiaen d'Hane, ridder en heer van Weldene, voor 12 geschilderde glasramen met d'Hanes wapenschild. Het is duidelijk dat deze ramen verschillen van het neutrale glas dat Van Bommele leverde. Van Bommele kon zijn ramen direct leveren, in tegenstelling tot Heijlbroeck, die het glas eerst diende te bewerken.

Diezelfde Van Bommele herstelde in 1686-1687 voor het bedrag van 227 gr. Vl. de glasramen van de kapel van de meerseniersnering in de Sint-Niklaaskerk te Gent. Herstellingen en reparaties werden namelijk veelvuldig uitgevoerd. Dit gebeurde steeds naar aanleiding van een specifieke opdracht. Bovendien waren herstellingen niet typisch voor glazenmakers. De schilder Lucas (I) Horenbault verdiende 720 gr. Vl. om samen met zijn zoon François in te staan voor het restaureren van diverse schilderijen aanwezig in verschillende kamers van het schepenhuis (1599-1600). In 1633 ontving Antonius van den Heuvele eveneens 720 gr. Vl. voor het reinigen van het Lam Gods van de gebroeders Van Eyck. In 1687 herstelde de beeldsnijder Gerij Pick een Jupiterbeeld op het stadhuis en in 1743 repareerde de beeldhouwer Jacques Gaerens verschillende beelden in opdracht van de stad. Dit is maar een kleine greep uit het overvloedig aantal herstellingen verricht door leden uit de populatie. Deze verschillende vormen van reparaties zorgden bij een deel van de kunstenaars voor een aanvullend inkomen. Hoewel deze activiteiten gebeurden op bestelling en in opdracht staan ze toch los van het eerste type kunstmarkt.

\subsubsection{Klantenkring van de kunstenaar}


Er waren diverse redenen om kunstwerken te bestellen en dit gebeurde zowel door instellingen en corporaties als door individuen. Sommige werken werden besteld om in openbare gebouwen, zoals kerken, zichtbaar voor iedereen te worden opgesteld. De opdracht hiertoe ging uit van de kerkfabriek zelf, van de leden van een gilde of een broederschap die bijeenkomsten hielden in die kerk of van een particulier die het werk schonk of het een plaats gaf in zijn familiekapel. Een individu kon echter ook een kunstwerk bestellen voor privégebruik, gewoon voor zijn plezier, uit ijdelheid of uit religieuze overtuiging. ${ }^{113}$

\section{Hof}

De staatkundige concurrentieslag woedde niet enkel op het slagveld. Ook op het artistieke vlak trachten concurrerende machten elkaar te overbluffen. Kunstenaars droegen bij tot de grandeur van de vorst. De middelmaat volstond echter niet en Gentse kunstenaars drongen dan ook niet vaak door tot de hofkringen. Meesters in dienst van het hof ontvingen vaak een vast jaarloon, dat niet noodzakelijk, maar vaak wel, hoger lag dan dat van hun collega's in het ambacht. ${ }^{114}$ Vermoedelijk genoten ze wel een hoger prestige. Als hofkunstenaar behoorden zij immers tot het hofpersoneel, wat hun positie op de maatschappelijke ladder ten goede kwam. De reeds vernoemde Gaspar de Crayer kan hierbij gelden als typevoorbeeld. In 1635 werd hij benoemd tot hofschilder in dienst van kardinaalinfant Ferdinand, een functie die hij behield onder landvoogd Leopold-Willem. De waardering die hij verwierf was enorm, zodanig zelfs dat Filips IV in hoogsteigen persoon een bestelling plaatste. Andere Gentse kunstenaars slaagden er eveneens in zich aan hoven op te werken, verspreid over het Europese continent. Anselmus Hebbelynck trad als hofschilder in dienst van Frederik Hendrik van Oranje. Op diens verzoek trok hij in 1647 naar Munster om de aanwezigen op het Westfaalse Vredescongres te portretteren. De volgende jaren vertoefde hij aan verschillende Duitse hoven en in 1652 belandde hij te Wenen. Daar trad hij in dienst van keizer Ferdinand III, die hem tevens verhief in de adelstand. Qua sociale mobiliteit kon dit wel tellen. Ook Filips Heunich trad in dienst van de keizer. Nicolas de Liemakere was eveneens actief in het Duitse gebied. Op verzoek van zijn leermeester Otto Venius trok hij naar Ferdinand II van Beieren, de prinsbisschop van Paderborn, waar hij werd overladen met voordelen en bestellingen. Afkomstig uit een familie van glasschilders, botste het hofleven met zijn karakter. Dit werkte zijn terugkeer in de hand. Verder was Jacobus de Leijen actief aan het Franse hof. Op 6 juli 1728 werd hij benoemd tot hofschilder van Lodewijk XV. Aan het hof van George II en III te Engeland slaagde Pieter Johannes van Reijsschoot, bijgenaamd de Engelsman, erin zich te onderscheiden als hofschilder.

Tot slot is het mogelijk op te merken dat opdrachtgeving vanuit het hof heel divers kon zijn. Zo verzorgde Laurentius Norbertus Heijlbroeck in 1752 een medaille voor Maria-Theresia. Philippe Lambert Joseph Spruijt stelde eveneens op last van Maria-Theresia een catalogus samen met alle kunstwerken aanwezig in Zuid-Nederlandse kerken en kloosters.

\section{Adel}

In de hotels van edellieden waren kunstwerken niet weinig aanwezig. De $18^{\text {de }}$-eeuwse beeldsnijder François Allaert vervaardigde bijvoorbeeld verschillende decoratieve beeldhouwwerken voor zijn mecenas, ridder F.J. de Coninck. De Gentse schildersfamilie Van Reijsschoot werd vaak ingehuurd door lokale edelen. Vader Emanuel verrichte meermaals arbeid voor de baron van Eksaarde. In 1762 voerde hij twee reparaties uit voor 96 gr. Vl. Drie jaar later ontving hij 4560 gr. Vl. courant voor het schilderen en vergulden van een wagen.

\footnotetext{
${ }^{113}$ MARTENS, De cliënteel van de kunstenaar, p. 144.

${ }^{114}$ CORNELIS, De kunstenaar, I, p. 182, 202; BRULEZ, Cultuur en getal, p. 74.
} 
Zijn zoon Pieter-Norbert stond in voor de versiering van het prachtige Hotel d'HaneSteenhuyse in de Veldstraat. Hij versierde de wanden en zoldering en werd hierbij voor het inkleuren bijgestaan door zijn broer Jan-Baptiste en zijn zuster Anna-Maria. Dit project leverde Pieter-Norbert maar liefst 120000 gr. Vl. op. Verder bracht hij nog salonversieringen aan, onder meer in hotel Faligan (Kouter, Gent) en in de huizen van ridder De Ghellinck (Zwijnaarde), baron Frederic Vander Bruggen-De Nayer en oud-senator Lammens (Houtlei, Gent). Een andere telg van de familie, Pieter-Johannes, broer van Emanuel, schilderde dan weer het werk Portret van de hertogin van Norfolk.

De "conspicuous consumption" van edelen bleef niet beperkt tot het eigen huishouden. Meermaals plaatste men bestellingen bij kunstenaars voor werken op publieke plaatsen. Op deze wijze kon de bevolking meegenieten van de rijkdom van de edelen en bovendien was het allerminst nadelig voor de populariteit van de betreffende aristocraat. Zo schilderde De Crayer een reeks van 12 taferelen, ter versiering van de kerk van het cisterciënzerklooster van Nazareth bij Lier (1652-1655). Elk schilderij werd bekostigd door een verschillende schenker. Willem Bete, markies van Lede en kapitein-generaal van de Spaanse vloot in de Lage Landen; Maximiliaan van Nassau, baron van Warcoing en Philippe-François de Fourneau, baron van Kapellen, waren enkele van deze schenkers.

Edelen wensten niet enkel in weelde te leven, ze verlangden ook te worden begraven in stijl. Hun grafmonumenten dienden waardigheid en luxe uit te stralen. Vaak werd dan ook een beroep gedaan op kunstenaars voor het vervaardigen van mausolea. De uit Antwerpen afkomstige beeldsnijder Jacques Cockx fabriceerde in 1655 het mausoleum van de familie Hélias d'Huddeghem. Gery Pick maakte het familiegraf voor de familie Van den Bosch. Naast mausolea kwamen ook andere grafversieringen voor. Benjamin Samelinck schilderde Het portret van de leden van de familie Plantijn (1591) voor het epitaaf van de boekdrukker Christoffel Plantijn in de Antwerpse Onze-Lieve-Vrouwkerk. Het werk is helaas verloren gegaan.

Deze praalzucht bleef niet beperkt tot de lokale aristocratie. Ook niet-Gentse edelen deden soms beroep op Gentse kunstenaars voor verfraaiingswerken. Het Portret van de hertogin van Norfolk van de hand van Pieter-Johannes van Reijsschoot werd hierboven reeds aangehaald. Adriaen Clayssens, gespecialiseerd in het verven van blazoenen, ontving in 1705720 gr. Vl. voor het schilderen van het wapenschild van de hertog van Beieren.

\section{Centrale, gewestelijke en lokale bestuursinstellingen}

In de steden, zo ook te Gent, bestond een traditie van Blijde Inkomsten. Deze ontvangsten groeiden in West-Europa uit tot ware apotheosen van pracht en praal. Zo ook in de Nederlanden, waar deze traditie bleef bestaan tot aan de Franse Revolutie. De Blijde Inkomst had niet louter tot doel de nieuwe vorst aan de bevolking voor te stellen. Bovendien was het de enscenering van de plechtige akte waardoor elke prins verplicht werd te erkennen dat zijn macht beperkt was door de rechten en privilegies van zijn onderdanen. Dit had het karakter van een contract tussen de vorst en het volk. ${ }^{115}$ Dergelijke inhuldigingen van de graven van Vlaanderen gingen gepaard met een buitengewoon prachtvertoon en gaven aanleiding tot enorme uitgaven. Vaak zorgden de Staten van Vlaanderen voor de inrichting van de plechtigheid. Het was dus niet steeds de stad Gent die de verfraaiingen bestelde. ${ }^{116}$ Bij de intocht van Filips V van Anjou in 1702 verdiende de beeldhouwer Norbertus Sauvage 133488 gr. Vl. voor het vervaardigen van een theater. Zijn zoon, de schilder Norbertus Sauvage, ontving 82296 gr. Vl. voor de beschildering ervan. Nog eens 18036 gr. Vl. inde hij voor het

\footnotetext{
${ }^{115}$ C. VAN DE VELDE, H. VLIEGHE, Stadsversieringen te Gent in 1635 voor de blijde intrede van de kardinaal-infant (Gent, 1969), p. 11.

116 SAG, Nota's van Werveke 587.
} 
aanbrengen van straatdecoraties voor dezelfde intocht. Voor de intrede van de kardinaalinfant Ferdinand in 1635 werden verschillende van schilderwerk voorziene versieringsconstructies uitgevoerd. Op de Vrijdagmarkt werden twee triomfbogen, de Arcus Fernandi en de Arcus Caroli opgericht; twee pegma's verschenen in de stad, de ene voor de ingang van de Oudburg en de andere voor de noordelijke zijgevel van het Vleeshuis; op het Veerleplein werd een perspectivum, een galerij, geplaatst en voor het Prinsenhof werd een theatrum opgericht. ${ }^{117}$ Aan dit reusachtige project werkten liefst 12 schilders uit de populatie mee, die samen niet minder dan 262499 gr. Vl. verdienden. Daarenboven vervaardigde Jacques Cockx voor 20000 gr. Vl. de standbeelden van Filips IV en Ferdinand. Deze werden opgesteld voor het Gravenkasteel. Ook minstens 4 niet-Gentse kunstenaars (Jacob Francart, Theodoor Rombouts, Cornelis Schut en Gerard Seghers) werden ingehuurd voor het aanbrengen van versieringen. ${ }^{118}$ Dit was trouwens niet de enige gelegenheid waarbij kunstenaars uit diverse steden naar Gent werden uitgenodigd. In 1653 deed de stad bijvoorbeeld beroep op Erasmus II Quellinus voor het ontwerp van de stadsversieringen ter ere van de Blijde Intrede van aartshertog Leopold-Willem. ${ }^{119}$ Bij verschillende andere intochten waren eveneens kunstenaars betrokken, bijvoorbeeld bij deze van de aartshertogen Albrecht en Isabella in 1600 en bij de intrede van Maria-Theresia in 1744.

De verschillende centrale, gewestelijke en lokale bestuursinstellingen tooiden hun gebouwen en vergaderzalen met een enorme diversiteit aan kunstwerken. Door de staatkundige complexiteit en de hieraan verbonden verplichtingen in andere delen van zijn rijk was het voor de vorst slechts zelden mogelijk aanwezig te zijn op het grondgebeid van de Nederlanden. Het bestuur werd in handen gegeven van gouverneurs-generaal, met uitzondering van de regeerperiode van de aartshertogen Albrecht en Isabella. De feitelijke soeverein was echter niet totaal afwezig. Verschillende portretten in de diverse bestuurs- en rechtscolleges toonden uitdrukkelijk wie de machthebber was. Zo verzorgde bijvoorbeeld Jan de Cleef de werken Koning van Spanje en de Maagd van Vlaanderen en Portret van de vorst voor het stadhuis. Joannes van Volxsom schilderde De huldiging van keizer Karel VI als graaf van Vlaanderen door markies de Prié, op de Vrijdagsmarkt, de $18^{\text {de }}$ oktober 1717 (1718-1728). Gillis le Plat ontving in 16901440 gr. Vl. voor een schouwstuk voorstellende de koning en koningin van Spanje.

Op het Gentse grondgebied waren verschillende gerechtshoven actief. Onder meer de Raad van Vlaanderen, het College van Oudburg en de Gentse magistraat hadden er een onderkomen gevonden. ${ }^{120}$ Gedurende de vroegmoderne periode was het gebruikelijk om in gerechtszalen op een goed zichtbare plaats een schilderij te plaatsen. De onderwerpen van dergelijke taferelen hielden steeds verband met de rechtspraak en wezen op de gevaren van liegen en geloof in het slechte. Opmerkelijk is trouwens dat bepaalde delinquenten de kosten dienden te betalen voor kunstwerken die herinnerden aan de straf. Het was dus niet steeds de kas van de heerlijkheid of de gemeente die de taferelen financierde ter versiering van de justitiezalen. ${ }^{121}$ Jan de Cleef schilderde het tafereel Zinnebeelden der gerechtigheid voor het stadhuis. Gillis le Plat vervaardigde De valse eed in opdracht van de stad. Pieter Nicasius borstelde het tafereel Justitie (1647) voor de schepenzaal van de keure. Laatste Oordeelscènes bleken eveneens populair. Zo bestelden de schepenen van de keure een Laatste Oordeel bij Raphä̈l Coxcie, hofschilder van de aartshertogen Albrecht en Isabella. ${ }^{122}$ Naast schilderijen kwamen ook beeldhouwwerken voor. Passchier Gravier herstelde in 1731 bijvoorbeeld een justitiefiguur op

\footnotetext{
${ }^{117}$ VAN DE VELDE, VLIEGHE, Stadsversieringen te Gent, p. 19.

${ }^{118}$ VAN DE VELDE, VLIEGHE, Stadsversieringen te Gent, p. 21, 30, 32.

${ }^{119}$ DE BRUYN, Schilderkunst van de $15^{\text {de }}$ tot de $17^{\text {de }}$ eeuw, p. 147.

${ }^{120}$ SAG, Nota's van Werveke 1066, Symbolische schilderijen in de gerechtszalen.

${ }^{121}$ SAG, Nota's van Werveke 1062, De gerechtigheid en de kunst.

${ }^{122}$ SAG, Nota's van Werveke 1066.
} 
het stadhuis.

Zoals het veelvuldig voorkwam dat niet-Gentse kunstenaars kunstwerken vervaardigden voor Gent, zo was het niet minder uitzonderlijk dat andere steden of heerlijkheden beroep deden op Gentse kunstenaars. Nicolas de Liemakere schilderde bijvoorbeeld Laatste Oordeelscènes voor Assenede (1642) en Wachtebeke. In 1772 bracht de beeldhouwer en stoffeerder Dominicus Cruyt wapenschilden aan op het gemeentehuis van Assenede. De stad Kortrijk deed in 1682 beroep op Pieter de Vocht voor snijwerk. Enkele jaren later restaureerde Joannes-Baptiste van Moerkercke enkele taferelen voor diezelfde stad.

Kunstenaars hoefden niet noodzakelijk weg te trekken uit Gent op zoek naar werk. De stadsmagistraat deed beroep op hen voor het uitvoeren van decoratieve werken en andere arbeid. De verrichte inspanning kon heel divers zijn. Zo verdiende Lieven van der Schelden in 1578-1579 6000 gr. Vl. voor het vervaardigen van een wapenboek met de wapenschilden van de schepenen van beide schepenbanken, de pensionarissen en secretarissen, edelen en notabelen van de stad Gent, de overdeken van de weverij en de dekenen van de 53 neringen van de stad. Gaspard Arebaut ontving in 1654 verschillende betalingen voor het schilderen van de vier wijzers van het Belfort. Jan Heijlbroeck herstelde dan weer enkele glasramen van het stadhuis (1665). In 1686 plaatste de beeldsnijder Jan-Baptiste van Helderbergh een Italiaans schouw in de pensionariskamer op het stadhuis. François van Herseke beschilderde in 1701 een schouw in de schatkamer van het stadhuis. Lucien van Hoostenberghe ontving een betaling voor het marmeren en vergulden van een schouw in het stadhuis. De mogelijkheden waren quasi oneindig.

Tot slot bestond voor kunstenaars ook de mogelijkheid een vaste betrekking aan de stad in de wacht te slepen en zo een vaste vergoeding te verkrijgen. Alvorens men in dienst trad, diende men een eed af te leggen. Jan Heijlbroeck deed dit op 23 mei 1662 en werd aldus stedelijk glazenmaker. Andere kunstenaars in vaste dienst waren de stadsschilder Arent van Wijnendale, de stadsmetselaar Tobias Oosterlijnck en de stadssteenhouwers Pieter Maes, Guillaume Pieters, Lieven en Pieter Plumion. Deze laatste was bovendien belast met de inspectie van de stedelijke gebouwen. Wat deze functies in stadsdienst inhielden, is niet steeds duidelijk. Toch lijkt het me niet verkeerd te stellen dat een dergelijke betrekking een zekere waardering inhield.

\section{Stedelijk patriciaat}

De verstedelijking in Vlaanderen ging gepaard met een toenemend overwicht van de burgerstand. De Gentse burgerij besteedde grote sommen aan artistieke creaties en andere curiosa. Zij wilden helemaal niet onderdoen voor de edellieden als het ging om de pracht van hun interieur. Met allerlei mooie voorwerpen werden hun woonvertrekken opgesmukt. ${ }^{123} \mathrm{Zo}$ ontving Gillis le Plat 960 gr. Vl. van een geneesheer voor het schilderij De Maagd van Gent (1690). Hij schilderde bovendien Portret van de Gentse kaligraaf Erasmus van de Steene, een van de weinige Gentse burgerportretten waarvan zowel de uitvoerder als de geportretteerde gekend zijn. Ook Pieter-Norbert van Reijsschoot bracht versieringen aan in diverse patriciërswoningen.

\section{Gilden, ambachten en broederschappen}

De corporaties creëerden eveneens werkgelegenheid voor de kunstenaars. Verschillende corporaties hadden een eigen ambachtshuis ter beschikking. Vaak werd dit verfraaid met allerlei kunstwerken. Zo herstelde Jan Heijlbroeck in 1653 de glasramen van het neringhuis

\footnotetext{
${ }^{123}$ DUVERGER, Gentse kunstverzamelingen voor 1797, pp. 49, 51-52.
} 
van de goudsmeden. Deze taak werd in de periode 1655-1657 vervuld door Joos d'Haene. Philippe Lambert Joseph Spruijt ontving 12000 gr. Vl. voor 2 schilderijen (Kanonschieting en Mortierschieting) die hij vervaardigde in opdracht van de schuttersgilden. Elk geportretteerd lid diende 168 gr. Vl. te betalen. François van Cuyck alias Mirop schilderde als dilettant in 1678 Groepsportret van de gilde van de beenhouwers, uit dankbaarheid voor zijn verkiezing als overste. Van Cuyck was trouwens de enige overste die zelf actief was in de kunstwereld.

Bovendien beschikten corporaties vaak over een kapel in een kerk, welke ze inrichtten en versierden. Hierdoor speelden ze eveneens een rol als opdrachtgevers voor kunstenaars. Zo verdiende Philips Wellens 398 gr. Vl. voor het herschilderen van 3 beelden in de kapel van de bakkers in de Sint-Baafskathedraal (1613-1614). François van Bommele leverde glasvensters aan het gilde van Sint-Sebastiaan (1683-1684) en herstelde de ramen in de kapel van de meerseniersnering in de Sint-Niklaaskerk (1686-1687). Jan Bossuyt herstelde op zijn beurt de kapelramen van de nering der metselaars en steenhouwers, eveneens in de Sint-Niklaaskerk (1662-1663). Jan de Cock ontving 480 gr. Vl. voor in een fries van een altaartafel, in de kapel van de schrijnwerkers in de Sint-Jacobskerk, de letters van de namen van de bestuursleden te vergulden (1614-1615).

Corporaties deden ook een beroep op kunstenaars voor het vervaardigen van gebruiksvoorwerpen. Joannes Colijn maakte, meer dan waarschijnlijk in zijn hoedanigheid van schrijnwerker, een koffer voor de kunstenaarsnering. Norbertus Sauvage graveerde 11 stalen stampers voor de wolwevers aan 36 gr. Vl. het stuk (1699). Antoon Baert maakte in 1743 toortsmodellen voor de schrijnwerkers. Joannes Hebbelinck verzorgde voor 1440 gr. Vl. courant de lindehouten bekroning van 2 toortsen (1706), gebruikt in een processie door de nering van de metselaars en steenhouwers. Indien Hebbelinck de deadline overschreed, verminderde zijn gage wel met 240 gr. Vl. Voor het vervaardigen van vaandels bleken kunstenaars eveneens de aangewezen personen. François de Drijver naaide, schilderde en vergulde het gildevaandel van het Sint-Lucasgilde in de jaren 1690-1691 voor 1648 gr. Vl. Andries Cools verdiende 2000 gr. Vl. voor het schilderen van het vaandel van het schermersgilde (1626-1627). Voor de rederijkerskamer Maria ter Eere vervaardigde Jan Stadius een nieuw vaandel, voorzien van een geschilderd medaillon (1626).

\section{Religieuze instellingen}

Rond 1600 kreeg het katholicisme de gelegenheid om de centrale plaats in het leven te herveroveren. De Contrareformatie werd de drijvende kracht voor het cultuur- en geestesleven. De bisschoppen, parochiegeestelijkheid en de kloosterorden toonden hernieuwde belangstelling voor de kunst. ${ }^{124}$ In het kader van de Contrareformatie ontstond zo een ruime binnenlandse afzetmarkt voor kunstvoorwerpen die de nieuwe ideologieën konden propaganderen. ${ }^{125}$ De kerken werden luisterrijk versierd werden met triomfantelijke barokke kunstwerken. ${ }^{126}$

Gentse kunstenaars werden dan ook veelvuldig aangesproken door de religieuze instellingen die gevestigd waren op het grondgebied van de stad. Allerhande kunstwerken werden vervaardigd ter versiering van de gebouwen en deze toonden de hernieuwde levenskracht van het katholicisme. Gijselbrecht van Beveren sneed een standbeeld van de Heilige Cecilia voor de Sint-Michielskerk (1735). Philippe Martens verzorgde de marmeren bekleding van de SintMichielskerk (1712) en de Sint-Baafskathedraal (1713). Ook Gillis Matthijs was verantwoordelijk voor een deel van de marmeren bekleding van de Sint-Michielskerk (1670).

\footnotetext{
${ }^{124}$ DUVERGER, Kunstgeschiedenis der Nederlanden, p. 2.

${ }^{125}$ H. SOLY, "Economische en sociaal-culturele structuren: continuïteit en verandering", in J. VAN DER STOCK (eds.), Stad in Vlaanderen: cultuur en maatschappij 1477-1787 (Brussel, 1991), p. 36.

${ }^{126}$ L. BEHEYDT, Eén en toch apart: kunst en cultuur van de Nederlanden (Leuven-Zwolle, 2002), p. 34.
} 
De marmeren bekleding van de Sint-Jacobskerk is dan weer van de hand van Jacobus Martens (1754). Gerard van Poecke schilderde verschillende processtaties voor de Sint-Martinuskerk voor het bedrag van 426 gr. Vl. (1665-1669). Glazenmakers kwamen eveneens aan hun trekken. Zo leverden Jan Bossuyt en Adriaen Hauwaert 27 kerkvensters bij de bouw van de sacristie in de Sint-Michielskerk (1650). Marten David en Cornelis Horenbault leverden ramen voor de Sint-Martinuskerk (1624-1625). Leden van het Sint-Lucasgilde ontwierpen eveneens kerkmeubelen. Ludovicus Cnudde maakte een altaarmodel voor de SintMichielskerk (1714-1715), net als François Coppens (1718-1719). Niet enkel de ontwerpen werden verzorgd door leden van het gilde, ook de feitelijke uitvoering was in hun handen. Ommaert Donckeur vervaardigde samen met Glaude le Fer het houten hoofdaltaar van de Sint-Michielskerk (1676). Diezelfde Le Fer stond reeds in voor het hoofdaltaar van de SintNiklaaskerk (1670-1673). Preekstoelen en tabernakels werden eveneens in groten getale besteld. Gerij Pick vervaardigde bijvoorbeeld een preekstoel voor de Sint-Niklaaskerk (16691670), net als Norbertus Sauvage (1670). Jacobus Coppens makte dan weer een tabernakel voor de Sint-Baafskathedraal (1719-1720). Kunstenaars stonden evenzeer in voor decoratieve werken. Zo verzilverde Gaspard Arebaut een kist en verschillend engelen in de SintNiklaaskerk, wat hem 2562 gr. Vl. opleverde (1658-1661).

De Contrareformatie had tevens een nieuwe bloei van het kloosterwezen tot gevolg. Deze instellingen bleven niet achter op kunstzinnig gebied en verfraaiden hun abdijen met kunstwerken door lokale kunstenaars. De versieringswerken konden van velerlei aard zijn. Gillis Joannes Eeckhaute verniste een Onze-Lieve-Vrouwbeeld in opdracht van de abdij van Baudeloo (1778). Diezelfde abdij betaalde 3840 gr. Vl. in 1718 voor Een landschap (1718) aan François van Hattem. Rombaut Pauwli verdiende maar liefst 122258 gr. Vl. voor een altaar dat hij vervaardigde voor het klooster van de Nieuwen Bosch (1657-1667). Jacques Liemaekere was herhaaldelijk actief voor de Groenenbrielabdij (1615-1620).

Dit is maar een kleine greep uit de enorme hoeveelheid kerkelijke bestellingen die gedurende de onderzoeksperiode werden geplaatst bij leden van het Sint-Lucasambacht. Velen werkten bovendien niet enkel voor religieuze instellingen gelegen in de stad Gent. Vanuit Vlaanderen stroomden de bestellingen toe. Robert Jolyt schilderde voor de kerk van Merendree $D e$ geboorte van Christus (1651). De schilder Philips Beernaert werkte regelmatig in opdracht van de kerk van Bassevelde (1650-1657). François Allaert sneed een preekstoel voor de SintMaartenskerk te Moerzeke (1774).

Het onderhoud van dit enorme kunstpatrimonium verzekerde ook werkgelegenheid. Pieter Maes restaureerde 2 schilderijen in opdracht van de abdij van Baudeloo (1786). Antonius van den Heuvele herstelde en vergulde het werk Onze-Lieve-Vrouw-Boodschap voor de SintNiklaaskerk te Gent (1645). Joannes Pennoqin werd 2440 gr. Vl. betaald voor het herstellen van enkele beelden en andere ornamenten in het hoogkoor van de Sint-Maartenskerk te Aalst (1703-1711).

\section{Caritatieve instellingen}

De stad herbergde eveneens liefdadigheidsinstellingen. Ter versiering van hun gebouwen deden ook zij beroep op kunstenaars. Zo vervaardigde Vincent van Biervliet een figuur voor het vondelingentehuis te Doornik (1611). Martinus de Reu stond in voor het witten en het olieverven van het godshuis (1736-1739).

Bovenstaande analyse maakt duidelijk dat er een markt voor kunst was. De vraag naar creaties was groot en kunstwerken gingen vlot van de hand. Daarnaast was het voor kunstenaars mogelijk bij te verdienen als kunstschatter en kunsthandelaar. Zij beschikten immers over de nodige expertise. Ignatius de Becker schatte bijvoorbeeld de waarde van de schilderijen bij 
het overlijden van Jan-Baptiste de Kimpe in 1742. Pieter Norbert van Reijsschoot bepaalde in 1787 onder meer de waarde van de verzameling van graaf Emanuel van der Meersch, heer van Berlare. Melchior de la Mars en Adriaenus de Grif waren actief als kunsthandelaars. De borduurder Jacobus de Rinck bezat een winkel waar naast goud- en zilverdraden ook Spaanse snuif kon worden gekocht.

Volstonden al deze potentiële inkomstenbronnen nu voor de kunstenaar om zichzelf en eventueel een gezin te onderhouden? Deze complexe vraag is persoonsgebonden. Financieel stonden kunstenaars immers niet even sterk. Vooreerst is het opmerkelijk dat slechts uitzonderlijk sporen van crisis opduiken. Op 28 januari 1666 schreef Servaes Manilius vanuit Parijs een brief aan zijn moeder. Hij deelde mee dat hij de terugreis niet dadelijk zou aanvatten, aangezien het ambacht van beeldsnijder te Gent niet rendabel was. Het volgende jaar was hij echter wel aanwezig te Gent, waar hij het meesterschap verwierf. Aan het einde van de $17^{\text {de }}$ en in de loop van de $18^{\text {de }}$ eeuw bleek tevens dat bepaalde suppoosten het jaarlijkse lidgeld niet betaalden. Als reden gaven ze op dat ze geen werk hadden uitgevoerd, aangezien de economische conjunctuur niet gunstig was. Zo betaalde Boudewijn Schoonheit in 1739 geen lidgeld, net als Jacobus van Perren. Anderen, zoals Jan de Prat in de jaren 1684-1687 en Antoon van de Rostijne in de periode 1698-1700, konden niet betalen door hun sobere staat. 23 meesters riepen deze reden één of meerdere malen in. Wetende dat het Sint-Lucasgilde gedurende de volledige onderzoeksperiode 859 nieuwe meesters verwelkomde, betekent dit dat amper 2,68 \% van de leden op een bepaald moment wegens gebrek aan financiële middelen het lidgeld niet kon ophoesten. Eén van deze 23, Pieter d'Haese betaalde trouwens later zijn achterstallig lidgeld. Bovendien is het opmerkelijk dat quasi geen enkel individu opdook in professionele contexten buiten de kunstwereld, het dubbel lidmaatschap terzijde gelaten.

Niet iedereen verdiende weliswaar de exuberante bedragen die bijvoorbeeld een De Crayer kreeg, maar de vraag leek groot genoeg om de volledige groep kunstenaars aan het werk te zetten. Het kunstenaarsbestaan bleek dus leefbaar te zijn in het vroegmoderne Gent. Dit lijkt eigenlijk wel logisch. Individuen die het meesterschap verwierven hadden een zeker vertrouwen in hun potentieel. Indien men vreesde dat men het als meester niet zou rooien, betaalde men immers niet het vereiste inschrijvingsgeld en het jaarlijkse lidgeld. Dan leek het beter als knecht een andere meester te dienen of actief te zijn in andere sectoren.

\subsection{Corporatieve bestuur}

Het corporatieve leven bood ambachtsmeesters vele mogelijkheden. Vrij spel hadden ze echter geenszins. Alle suppoosten van de gilde dienden zich te schikken naar de verschillende regels en waren gehoorzaamheid verschuldigd aan de oversten en gezworenen van de nering. ${ }^{127}$ In dit deel staat het hoogste sociaaljuridische niveau van het ambacht centraal, het bestuur.

\subsubsection{Samenstelling}

Ambachten werden geleid door een eed, een jaarlijks wisselend bestuurscollege, waarvan de leden een eed van getrouwheid aflegden tegenover de stadsmagistraat die hen aanstelde. ${ }^{128}$ Het ambacht van de kunstenaars week deels van dit patroon af. Het bestuurscollege, bestaande uit de overste en de gezworenen, bleef soms enkele jaren de leiding van het ambacht in handen houden. Zo werd het bestuurscollege in de periode 1666-1670 gevormd door de overste Jan van der Beke en de gezworenen Gerij Pick en Pieter Ameloot. Van der Beke

\footnotetext{
127 SAG, Reeks 183-1, fol. 17 vo .

${ }^{128}$ DAMBRUYNE, De Gentse bouwvakambachten, p. 101.
} 
bekleedde gedurende de jaren 1649-1651 ook de functie van overste. Het gegeven dat gedurende de periode 1574-1773 amper 91 verschillende oversten vermeld worden, toont eveneens aan dat het bestuur niet jaarlijks vernieuwd werd. ${ }^{129}$

In het bestuurscollege was sinds de Concessio Carolina, met uitzondering van de calvinistische periode, steeds één overste aanwezig. Afhankelijk van de tijdsperiode kreeg deze ook soms de titel van deken, overdeken of hoofdman. Zij werden aangeduid door de stadsmagistraat en de hoogbaljuw voor een mandaatschap. Deze oversten oefenden geen ambacht uit en behoorden tot de gefortuneerde stedelijke elite. De functie werd meestal toegekend aan leden van de stadsadel ${ }^{130}$ of aan beoefenaars van vrije beroepen, zoals advocaten of dokters. ${ }^{131}$ De Sint-Lucasgilde volgde dit patroon. Liefst $57(62,64 \%)$ oversten werden met zekerheid gekozen uit de stadsadel. Vier droegen de titel van ridderjonkheer, 53 anderen droegen uitsluitend de benaming jonkheer. De Gentse adel stamde af van de middeleeuwse patricische families. Vanaf het einde van de $16^{\text {de }}$ eeuw lieten de meesten zich de titel jonkheer aanmeten. Ook één meester werd omschreven als jonkheer, Jan-Baptiste de Lattre. Zijn sociale achtergrond bleek dus de stedelijke elite. Ook Anselmus Hebbelynck combineerde het kunstenaarschap en het edelschap. Hij was echter geen edelman van geboorte. Bovendien bezaten de meeste Gentse edellieden heerlijkheden gedurende de vroegmoderne periode. ${ }^{132} 19$ oversten bleken inderdaad heer van een heerlijkheid. Daarenboven telde de groep van de oversten ook nog 7 rechtsgeleerden en 2 geneesheren. Andere taakomschrijvingen waren ontvanger (onder meer van de huisgelden), opperbaljuw van Sint-Baafs en kapitein van de burgerwacht. Deze laatste functie was niet typisch voor oversten. Ook Hendrik Matthijs vulde deze functie in.

Oversten van een ambacht bleven soms meer dan één jaar aan. Bovendien was er geen beperking tot het hoofdmanschap van een welbepaalde gilde. Na afloop van een mandaat kon men overste worden van een ander ambacht. Van 10 van de 91 oversten kan met zekerheid gezegd worden dat ze ook in andere ambachten actief waren als overste. Vooral het ambacht van de goudsmeden bleek populair. François van Cuyck was naast overste van de SintLucasgilde ook overste van de ambachten van de meubelmakers, de slagers, de winkeliers en wassenkaarsmakers. Hij bleek tevens dilettant en was dus actief als amateurschilder. Dit is hoogst uitzonderlijk, aangezien de oversten van het technische aspect van de ambachten, die onder hun bevoegdheid stonden, geen kaas hadden gegeten. Om deze reden werden zij bijgestaan door gezworenen. ${ }^{133}$ Hierbij dient wel een kanttekening te worden gemaakt. Gedurende de Calvinistische Republiek draaide men namelijk de klok terug. De overste mocht wel een persoon uit het eigen midden zijn, een ambachtsman in hart en nieren. Dit was immers de geldende regel vóór de Carolijnse Concessie. Het curriculum vitae van Pieter van Hecke kan als voorbeeld dienen. In 1575 trad hij op als gezworene van het ambacht. In 1583 was hij overste. Na de val van het calvinistisch regime zou geen enkele ambachtsman nog doordringen tot de positie van overste. De overste kreeg een vergoeding van 240 gr. Vl. per jaar. ${ }^{134}$ Bovendien werd hij getrakteerd op de dag van de Heilige Lucas, de patroon van de gilde. De uitgave van de traktatie mocht wel het bedrag van 480 gr. Vl. niet overschrijden. ${ }^{135}$ Het ambacht was voor de oversten een onbekende wereld. Zij werden dan ook bijgestaan door gezworenen, ook wel deken genoemd. De Carolijnse Concessie bracht het aantal gezworenen

\footnotetext{
${ }^{129}$ De afwezigheid van enkele jaren in het bronnenmateriaal in acht genomen.

${ }^{130}$ L. DUERLOO, P. JANSSENS, Wapenboek van de Belgische adel van de $15^{\text {de }}$ tot de $20^{\text {ste }}$ eeuw (Brussel, 1992), II, pp. 44-45: de adellijke rangen zijn jonkheer, ridder en de getitelde adel, met name in oplopende volgorde baron, burggraaf, graaf, markies, prins en hertog.

${ }^{131}$ DAMBRUYNE, De Gentse bouwvakambachten, p. 101.

${ }^{132}$ DAMBRUYNE, Economische conjunctuur en sociale structuren, p. 125

${ }^{133}$ DAMBRUYNE, De Gentse bouwvakambachten, p. 101.

${ }^{134}$ SAG, Reeks 183-5.

${ }^{135}$ SAG, Reeks 183-3.
} 
in de meeste ambachten terug van vier op twee. ${ }^{136}$ Dit was ook het geval voor het kunstenaarsambacht. De bestuurslijsten, terug te vinden in het Schildersboeck, tonen dit aan. Enkel voor het jaar 1626 werd maar één gezworene genoteerd, Jan Stadius. ${ }^{137}$ Het is niet duidelijk of er maar één gezworene was of als men de tweede gezworene gewoonweg vergat op te tekenen. In 1657 leek het aantal gezworenen wel te veranderen. Het reglement luidde: 'Item datter t' elcker waerf jaerlicx zullen t' saemen ghemaeckt worden drij dekens, te weten den eenen uuijt de schilders, den anderen uuijt de beeldesnijders ende den derden uuijt de glaesmaeckers". ${ }^{138}$ Schijn bedriegt echter. Het Schildersboeck bleef gedurende de jaren $1657-$ 1681 slechts twee gezworenen vermelden. Pas vanaf 1682 werd de beslissing in praktijk gebracht. ${ }^{139}$ Waarom pas een derde gezworene werd aangesteld na een kwart eeuw is onduidelijk. Net als vroeger dient ook hier de zucht naar het verleden ten tijde van het calvinistisch gezag worden benadrukt. Vier gezworenen werd opnieuw de regel. Dit blijkt uit het Schildersboeck. ${ }^{140}$

Tussen de eerste en de tweede gezworene was een hiërarchisch onderscheid, maar voor beiden gold dezelfde aanstellingsprocedure. Men kon bovendien herkozen worden. De gezworenen werden aangesteld door de overste en de gezworenen van de laatste twee jaar. Vorige bestuurscolleges hadden dus beslissingsrecht over hun opvolgers. De keuze werd vervolgens door de hoogbaljuw en de wethouders goedgekeurd of verworpen. In het laatste geval mocht men nieuwe kandidaten voordragen. ${ }^{141}$ Voor het jaar 1685 is deze verkiezingsstrijd te volgen. De corporatie bood de schepenen van de keure een lijst aan met negen namen, namelijk 3 schilders, 3 beeldsnijders en 3 glazenmakers. De magistraat kon vrij beslissen, maar diende natuurlijk uit elke groep 1 naam te selecteren. Vermoedelijk geschiedde deze procedure jaarlijks, aangezien de documenten uit 1685 uitdrukkelijk vermelden dat "Schepenen van der keure...denomeren...omme desen jeghenwordighen jaere te dienen als gheswoorne". ${ }^{142} \mathrm{Na}$ hun verkiezing dienden de gezworenen, net als de oversten, zich te begeven naar het schepenhuis om de eed af te leggen. Ook deze procedure werd meer dan vermoedelijk jaarlijks herhaald. ${ }^{143}$ Het afleggen van de eed ging gepaard met de nodige drank, maar de kosten van de vertering mochten de som van 48 gr. Vl. niet overschrijden. ${ }^{144}$

Net als bij de functie van overste was aan de positie van gezworene een financiële tegenprestatie verbonden. Elke gezworene verkreeg de helft van het loon van de overste voor zijn diensten, namelijk 120 gr. Vl. ${ }^{145}$ Rijk werd men dus niet van de topfuncties binnen het ambacht. Wel was aan beide functies inherent sociale mobiliteit verbonden. Welke functies individuen in het ambachtsbestuur bekleedden en hoe vaak zij dat deden, geeft immers een indicatie van hun sociale positie. ${ }^{146}$

\subsubsection{Takenpakket}

De overste en de twee gezworenen vormden samen een triumviraat dat instond voor het

\footnotetext{
${ }^{136}$ DAMBRUYNE, De Gentse bouwvakambachten, p. 101.

${ }^{137}$ SAG, Reeks 183-1, fol. $65 \mathrm{v}^{\mathrm{o}}$.

${ }^{138}$ SAG, Reeks 183-3.

${ }^{139}$ SAG, Reeks 183-1, fol. 112.

${ }^{140}$ SAG, Reeks 183-1, fol. 47.

${ }^{141}$ DAMBRUYNE, De Gentse bouwvakambachten, p. 101.

${ }^{142}$ SAG, Reeks 156bis nr 57.

${ }^{143}$ SAG, Reeks 183-1, fol. 16.

${ }^{144}$ SAG, Reeks 183-3.

${ }^{145}$ SAG, Reeks 183-3.

${ }^{146}$ K. VAN QUATHEM, "Sociale mobiliteit en machtsverdeling in het Brugse schoenmakersambacht (15701790)", in C. LIS, H. SOLY (eds.), Werken volgens de regels. Ambachten in Brabant en Vlaanderen, 1500-1800 (Brussel, 1997), p. 101.
} 
algemeen bestuur van het ambacht. Zij vertegenwoordigden het ambacht naar buiten toe, voor de stedelijke of centrale overheid. Bovendien beschikten zij over wetgevende en rechterlijke bevoegdheden. ${ }^{147}$ Het bestuurscollege zag toe op de naleving van de ambachtsreglementen door de leden en zij controleerden de ambachtelijke productie. In de praktijk betekende dit dat zij regelmatig huisbezoeken aflegden. Indien men onregelmatigheden opmerkte, behoorde het tot hun bevoegdheden om de overtreder boetes op te leggen. ${ }^{148}$ Men waakte minutieus over de kwaliteit van de gebruikte grondstoffen en de afgewerkte producten en men bewaakte het beroepsmonopolie. Zij hadden immers ook het recht om niet-leden te visiteren, het aangevatte werk stop te zetten en het gereedschap in beslag te nemen, of ze konden op zijn minst lagere stadsambtenaren de opdracht geven dit te doen. ${ }^{149} \mathrm{Bij}$ meningsverschillen tussen twee of meerdere suppoosten van het ambacht, trad het bestuurscollege op als bemiddelaar en probeerde men het conflict op te lossen. Indien men niet tot een oplossing kwam, diende men zich te wenden tot de magistraat. ${ }^{150}$ Strafrechtelijke zaken vielen buiten deze gerechtelijke bevoegdheid. Verder riepen de overste en de gezworenen de ledenvergaderingen bijeen en zaten ze deze voor. Beslissingen werden steeds met de meerderheid van de stemmen genomen. Het ambachtsbestuur ontwierp zelf de meeste reglementen, maar deze dienden nadien aan de schepenen en de hoogbaljuw worden voorgelegd ter goedkeuring. ${ }^{151}$ Dit kon soms problemen opleveren. Zo is een wetsvoorstel gekend uit 1683 met betrekking tot de aanen verkoop van kunstwerken, dat nooit officieel bekrachtigd werd. Het reglement bleek dus waardeloos. ${ }^{152}$ De gezworenen waren ook verantwoordelijk voor de optekening van nieuwe leerjongens en meesters, voor het noteren van de omstellingen en voor het bijhouden van de ambachtsrekeningen. Het uittredend bestuur diende in aanwezigheid van de schepenen en de nieuwe bestuursleden rekenschap af te leggen van hun mandaat. ${ }^{153}$ Bovendien waren de gezworenen verplicht binnen een termijn van acht dagen na het verlopen van hun ambt de rekening van hun ambtstermijn op te maken. ${ }^{154}$

\subsubsection{Sociale mobiliteit}

Zoals reeds aangehaald bleek een functie in het ambachtsbestuur een indicatie van de sociale positie van de leden. De vraag stelt zich nu naar de mogelijkheid om door te stoten naar het bestuur van de corporatie in functie van de beroepsgroep. Via het bronnenmateriaal was het mogelijk voor 184 jaar van de onderzoeksperiode de gezworenen te achterhalen. Er werd 468 maal een gezworene aangesteld. De invulling van deze bestuursfunctie gebeurde doorheen deze periode door 139 verschillende personen. Het is dus duidelijk dat meesters meerdere malen konden deel uitmaken van het bestuur van het ambacht. De fijnschilder François Baert was gedurende 11 jaar gezworene van de corporatie, de beeldsnijder Joannes Dupré zelfs 12 jaar. Daarentegen waren 37 meesters of $26,62 \%$ amper één jaar lid van het bestuurscollege. Als het cijfer 139 wordt bekeken in het licht van de totale populatie blijkt dat amper 16,18\% van de meesters kon doorstoten naar een bestuursfunctie. De functie van gezworene was dus duidelijk niet voor iedereen weggelegd. Het vervolg van het onderzoek naar sociale mobiliteit

\footnotetext{
${ }^{147}$ DAMBRUYNE, De Gentse bouwvakambachten, p. 101.

${ }^{148}$ SAG, Reeks $183-1$, fol. $16-16 v^{\circ}$.

149 H. DECEULAER, "Conflicten en conflictregeling in de Antwerpse ambachtswereld, 1585-1796. Een verkenning van de juridische en sociaal-politieke aspecten op het lokale terrein", in C. LIS, H. SOLY (eds.), Werken volgens de regels. Ambachten in Brabant en Vlaanderen, 1500-1800 (Brussel, 1997), p. 137; DAMBRUYNE, De Gentse bouwvakambachten, p. 101.

${ }^{150}$ SAG, Reeks 183-1, fol. 16.

${ }^{151}$ DAMBRUYNE, De Gentse bouwvakambachten, p. 102.

${ }^{152}$ SAG, Reeks 183-3.

${ }^{153}$ SAG, Reeks 183-1, fol. 18.

${ }^{154}$ SAG, Reeks 183-3.
} 
bij ambachtsmeesters wordt opgesplitst in twee delen, namelijk van 1574 tot en met 1681 en van 1682 tot en met 1773. De reden ligt voor de hand. Vanaf 1682 telde het bestuurscollege drie gezworenen in plaats van twee, wat invloed had op de sociale mobiliteit.

\section{4-1681}

Gedurende deze eerste periode waren 88 verschillende gezworenen actief, samen goed voor 193 maal de invulling van deze functie. 36 meesters of 40,91\% bleven slechts gedurende één jaar in functie. Drie personen oefenden gedurende zes jaar het ambt van gezworene uit, met name Bartolomeus de Haese, Jan Heijlbroeck en Claijs de Smet.

\begin{tabular}{|c|c|c|c|}
\hline $\begin{array}{c}\text { Ambtstermijn } \\
\text { gezworene }\end{array}$ & Aantal gezworenen & $\begin{array}{c}\text { Ambtstermijn } \\
\text { gezworene }\end{array}$ & Aantal gezworenen \\
\hline 1 & 36 & 4 & 6 \\
\hline 2 & 24 & 5 & 5 \\
\hline 3 & 14 & 6 & 3 \\
\hline
\end{tabular}

Tabel 5: ambtstermijn van de gezworenen (1574 - 1681)

Van 63 meesters is bovendien de datum gekend waarop zij het meesterschap hadden verworven. Gemiddeld diende men ruim 11 jaar te wachten voor men werd opgenomen in het bestuur. De onderlinge verschillen waren echter groot. Sommigen, zoals Pieter de Bruyne en Joannes-Baptiste Herseke, slaagden er na één jaar reeds in een bestuursfunctie in de wacht te slepen. Anderen dienden meer dan drie decennia te wachten op een dergelijke promotie. De uit Haarlem afkomstige glazenmaker Adriaen Hauwaert trad pas toe tot het bestuur van de gilde 36 jaar na het verwerven van het meesterschap. De mediaan ligt op 9 jaar.

Het is eveneens interessant om te kijken naar de professionele status van de gezworenen. Bleken bepaalde groepen kunstenaars systematisch het bestuur van het ambacht in handen te nemen of kwamen alle groepen kunstenaars evenveel aan bod in het bestuur?

\begin{tabular}{|c|c|c|}
\hline Professionele status & Aantal jaar gezworene & Aandeel (in \%) \\
\hline \hline Fijnschilders & 78 & 40,42 \\
\hline $\begin{array}{c}\text { Beeldsnijders en } \\
\text { steenhouwers }\end{array}$ & 42 & 21,76 \\
\hline Glazenmakers & 33 & 17,10 \\
\hline Onbekend & 23 & 11,92 \\
\hline Goudslagers & 9 & 4,66 \\
\hline Stoffeerders & 6 & 3,11 \\
\hline Huisschilder & 2 & 1,04 \\
\hline
\end{tabular}

$\underline{\text { Tabel 6: professionele status van de gezworenen }(1574-1681)}$

Tabel 6 toont aan dat schilders de meeste kans maakten op het ambt van gezworene $(41,45 \%)$, gevolgd door de sculpteurs en glazenmakers. Samen zijn deze drie groepen goed voor meer 
dan $80 \%$ van de gezworenen. De drie hoofdgroepen van het ambacht domineerden het bestuur gedurende de periode 1574-1681. Dit waren natuurlijk ook de groepen die het grootste aantal meesters representeerden.

\section{2-1773}

$53^{155}$ meesters slaagden erin gedurende deze tweede periode zich op te werken tot het bestuursniveau van het ambacht. Samen oefenden deze 275 maal de functie van gezworene uit. Amper één meester, de glazenmaker Louis Cosijn, was gedurende één jaar gezworene. De andere 52 bestuursleden bleven twee of meer jaar aan. Dit hoefde geen aaneengesloten periode te zijn. Men kon gerust in verschillende decennia opgenomen worden in het bestuurscollege van het ambacht. Joannes Dupré was gezworene van het ambacht gedurende de jaren 1747-1752 en opnieuw in de jaren 1763-1768. Met zijn in totaal twaalf jaar lidmaatschap van het bestuur had hij ook het record in handen.

\begin{tabular}{|c|c|c|c|}
\hline $\begin{array}{c}\text { Aantal jaar } \\
\text { gezworene }\end{array}$ & Aantal gezworenen & $\begin{array}{c}\text { Aantal jaar } \\
\text { gezworene }\end{array}$ & Aantal gezworenen \\
\hline \hline 1 & 1 & 7 & 7 \\
\hline 2 & 1 & 8 & 2 \\
\hline 3 & 14 & 9 & 0 \\
\hline 4 & 11 & 10 & 1 \\
\hline 5 & 4 & 11 & 1 \\
\hline 6 & 6 & 12 & 5 \\
\hline
\end{tabular}

Tabel 7: ambtstermijn van de gezworenen $(1682-1773)$

Voor 50 meesters is het bovendien ook mogelijk het jaartal van het bereiken van het meesterschap te vergelijken met het jaartal waarin men de eerste keer zetelde in het ambachtsbestuur. Men diende gemiddeld ongeveer 19 jaar te wachten voor men werd opgenomen in het bestuur. In dit opzicht is de drie jaar wachttijd van de fijnschilder François de Drijver en de beeldsnijder Livinus Helderbergh heel gering. Jan Cesaert had echter 58 jaar nodig om zich te kunnen opwerken tot het bestuursniveau. Het gemiddelde wordt sterk beïnvloed door deze uitersten, waardoor het berekenen van de mediaan een betere optie lijkt. Deze bedraagt 18 jaar.

Het ambachtsreglement van 1657 bepaalde dat het bestuur voortaan drie gezworenen telde, met name een schilder, een beeldsnijder en een glazenmaker. ${ }^{156}$ Dit artikel werd pas vanaf 1682 omgezet in de praktijk. De vraag stelt zich nu naar de naleving van het reglement.

\begin{tabular}{|c|c|c|}
\hline Professionele status & Aantal jaar gezworene & Aandeel (in \%) \\
\hline \hline Glazenmakers & 20 & 37,74 \\
\hline Beeldsnijders en & 15 & 28,30 \\
\hline
\end{tabular}

\footnotetext{
${ }^{155} 2$ meesters waren zowel gezworenen in de eerste als in de tweede periode, met name Jan de Cleef en Jan de Smet.

${ }^{156}$ SAG, Reeks 183-3.
} 


\begin{tabular}{|c|c|c|}
\hline beeldhouwers & & \\
\hline Fijnschilders & 15 & 28,30 \\
\hline Huisschilders & 2 & 3,77 \\
\hline Onbekend & 1 & 1,89 \\
\hline
\end{tabular}

Tabel 8: professionele status van de gezworenen $(1682-1773)$

Het overzicht van de professionele status van de gezworenen voor de tweede periode toont duidelijk aan dat het ambacht haar eigen reglement naleefde. De voorkeur ging inderdaad uit naar een (fijn)schilder, een beeldsnijder en een glazenmaker. De huisschilders hadden werkelijk geen vinger in de bestuurlijke pap te brokken. Dit gold in kleinere mate ook voor de borduurwerkers. Het aantal borduurwerkers was immers maar een fractie van het aantal huisschilders. De reden waarom beide groepen streefden naar autonomie is duidelijk. Het ambacht hield geen rekening met deze deelgroepen. Glazenmakers, beeldsnijders en fijnschilders namen de beslissingen, ook over zaken die de huisschilders of borduurders aanbelangden.

\section{4-1681 vs. $1682-1773$}

Enkel een kleine groep meesters met een welbepaalde professionele status kon genieten van de mogelijkheid van sociale mobiliteit via een bestuursfunctie in het ambacht. Daarenboven lijkt het bestuur in de periode 1574-1681 een "democratischer" en meer open karakter te hebben dan de leiding gedurende de jaren 1682-1773. Gedurende de eerste periode kwamen bestuurswissels regelmatig voor. Meerdere meesters konden proeven van de macht en deze periode werd gekenmerkt door kortere ambtstermijnen. Bovendien diende men minder geduld op te brengen dan in de tweede periode om effectief bestuurslid te worden. De tweede periode werd daarentegen gekenmerkt door minder vernieuwingen van het bestuur, met als gevolg dat de gezworenen langer aan de macht bleven.

De bestuursfunctie van gezworene lag niet binnen de mogelijkheden van elke meester. Niet eens 1/5 van de meesters stootte immers door naar het ambachtsbestuur. Daarenboven maakte men enkel een reële kans indien men actief was als fijnschilder, beeldsnijder of glazenmaker. De andere geledingen van het ambacht vielen al bij voorbaat uit de bestuurlijke boot. Op professioneel vlak was geen sprake van gelijkheid onder de verschillende leden van het ambacht.

\section{Conclusie}

Deze bijdrage had tot doelstelling meer inzicht te krijgen in de sociaaleconomische positie van de Gentse kunstenaars in de periode 1574-1773 op basis van een prosopografisch onderzoek. Spreken over kunstenaars in het Ancien Régime ligt vaak gevoelig, maar in hun kwaliteit als inventeurs en ontwerpers lijkt het voor het overgrote deel van de onderzoekspopulatie, de leden van de Sint-Lucasgilde, gerechtvaardigd. Hierbij is belangrijk dat de term kunstenaar slechts sporadisch iets te maken heeft met het aanzien van de betrokkene.

De leden van de Sint-Lucasgilde werden opgespoord aan de hand van drie verschillende bronnen: (1) het Schildersboeck, (2) de extracten en (3) de rekeningen. De corporatie bleek een uitermate gediversifieerd ledenbestand te hebben. Verschillende kunstenaarsgroepen ressorteerden namelijk onder de Sint-Lucasgilde. De belangrijkste waren de schilders (zowel 
fijn- als huisschilders), de sculpteurs, de glazenmakers, de stoffeerders en de borduurders. De gilde vormde de eenheid waarbinnen de verschillende ambachtsleden, enerzijds als groep en anderzijds als individu, hun weg zochten en carrière maakten.

Dit kunstenaarsbestaan behoorde echter niet voor iedereen tot de mogelijkheden. De aspiranten kwamen voornamelijk uit de middenklasse en vaak was hun vader reeds actief in het milieu. Vrouwen werden - quasi - alle kansen ontnomen. De opleidingstijd werd doorgebracht op de werkvloer, waar iedereen dezelfde basistechnieken kreeg aangeleerd. Afhankelijk van de specialiteiten van zijn leermeester kon de vorming van de kandidaatkunstenaar enigszins verschillen. Naast de opleiding bij een volleerd meester vond het concept van de academie ingang in het vroegmoderne Gent. De gilde en de academie stonden feitelijk los van elkaar. Via de academie kon men zich opwerken binnen de gilde, zich emanciperen. Het was een middel tot statusbevestiging.

$\mathrm{Na}$ het volmaken van de opleidingstijd was het voor leerlingen niet uitzonderlijk in loondienst te werken bij een meester. Deze periode als gezel of knecht kon ettelijke jaren duren en had verscheidene voordelen. Men kon zich verder bekwamen in het vak zonder zelf verantwoordelijkheid te dragen over een atelier. Bovendien kon men gedurende deze periode financieel sterker worden, om zo effectief de stap te zetten naar het meesterschap.

Dit meesterschap kon men enkel bereiken indien men poorter van de stad was, een goedgekeurde meesterproef kon voorleggen en indien men het intredegeld betaalde. Bovendien moest men jaarlijks een bijdrage storten in de gildekas. Het meesterschap bleek dus niet binnen ieders mogelijkheden te liggen. Toch verwierven gedurende de periode 15741773 maar liefst 859 individuen het statuut van meester. Eens men meester was, bleek men volwaardig lid van de gilde. Een dergelijk statuut had verscheidene voordelen. Men mocht vrij het beroep uitoefenen en beschikken over een eigen atelier en winkel. Zo kon men meegenieten van het corporatieve monopolie. Bovendien haalde elke individuele gildebroeder uit zijn lidmaatschap een superieure status, die samenhing met zijn handvaardigheid. Daarnaast hield dit lidmaatschap in dat sociale netwerken werden gevormd en in stand werden gehouden.

Individuen die het meesterschap bereikten hadden dus een gelijkaardig parcours afgelegd. Het vervolg van de carrière was minder eenduidig. De economische positie van de kunstenaar, en hiermee samenhangend dus ook de sociale positie van de kunstenaar, was natuurlijk afhankelijk van de afzet van zijn werken. De kostprijs van een kunstwerk verschilde van stuk tot stuk, aangezien de prijs onder meer werd bepaald door de grootte van het werk, de gebruikte materialen, de duur van het arbeidsproces en de uitvoering van het werk. Daarnaast speelde ook naambekendheid van de uitvoerder een zekere rol. Door al deze verschillen bleek het onmogelijk dé economische positie van dé kunstenaar te bepalen. Deze positie varieerde van kunstenaar tot kunstenaar. Toch waren gemeenschappelijke kenmerken aanwezig. Kunstenaars bereikten hun koperspubliek voornamelijk via werken uitgestald in hun winkel en op jaarmarkten. Daarnaast werden steevast ook bestellingen geplaatst. De precieze verhouding tussen deze verschillende opties bleek onmogelijk te bepalen. Duidelijk was wel dat het kunstenaarsbestaan leefbaar bleek. De afzetmarkt had immers een enorme omvang. Zowel vanuit het hof, de adel, het stedelijk patriciaat, bestuursinstellingen op alle niveaus, religieuze en caritatieve instellingen, als vanuit de corporatieve wereld was de vraag naar kunst heel groot en continu aanwezig. Bovendien produceerde men eveneens voor een anonieme markt, die jammer genoeg nauwelijks gedocumenteerd is. De omvang hiervan was zeker niet gering. Uiteindelijk bepaalden de inkomsten de welvaart en de sociale positie van de kunstenaar.

Naast een goede verdienste bleek het voor meesters uit de gilde van Sint-Lucas mogelijk zich sociaal op te werken via een bestuursfunctie in het ambacht. Dit lag echter niet binnen de mogelijkheden van elke meester, aangezien men het beroep van fijnschilder, sculpteur of 
glazenmaker diende te beoefenen om kans te maken.

Afsluitend kan worden gesteld dat Gent zeker niet het artistieke centrum was, maar toch een rol speelde in de vroegmoderne kunstmarkt. 